*ak RMIS View/Frint Document Cover Sheet tow

This document was retrieved from the Documentation and Records Manaqement (DRM) ISEARCH System. It is intended for Information only and may not be the most recent or updated version. Contact a Document Service Center (see Hanford Info for locations) if you need additional retrieval information.

Accession \#: D196000397

Document \#: SD-TD-CR-001

Title/Desc:

DESIGN CRITERIA FOR THE LDUA SYS END EFFECTORS

Pages: 44 


\begin{tabular}{|c|c|c|c|}
\hline \multirow{3}{*}{ 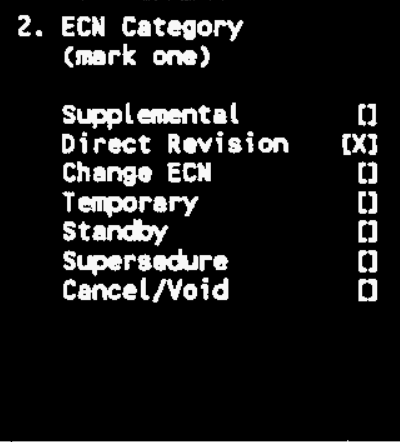 } & $\begin{array}{l}\text { 3. Originator's Hewe, Organization, MstM, } \\
\text { and Telephone No. } \\
\text { G. R. Kiebe1/Remote System and } \\
\text { Sensor Appl ications/N1-21/ } \\
\text { 376-4995 }\end{array}$ & $\begin{array}{l}\text { 3a. Uso Required? } \\
\text { [] Yes [X] No }\end{array}$ & $\begin{array}{l}\text { 4. Date } \\
11 / 30 / 95\end{array}$ \\
\hline & $\begin{array}{l}\text { 5. Project Title/No./Nork order No. } \\
\text { Light Duty Utility Arm }\end{array}$ & $\begin{array}{c}\text { 6. Bldg./5ys./Fac. No. } \\
\text { N/A }\end{array}$ & $\begin{array}{l}\text { 7. Approval Designator } \\
\text { N/A }\end{array}$ \\
\hline & $\begin{array}{l}\text { 8. Document Nubars Changed by this ECN } \\
\text { (ineludes shest no andigy.) } \\
\text { WHC-SD-TD-C-001, Rev. } 0\end{array}$ & $\begin{array}{l}\text { 9. Related ECN Mo(s). } \\
\qquad N / A\end{array}$ & $\begin{array}{l}\text { 10. Related PO Mo. } \\
\text { MRB-SXP-562953 }\end{array}$ \\
\hline $\begin{array}{l}\text { 11a. Modification Hork } \\
\text { [] Yes (fill out Blk. } \\
\text { 11b) } \\
\text { [X] Ho (m Blks. 11b, } \\
\text { 11G, 11d) }\end{array}$ & $\begin{array}{l}\text { 11c. Nodification Hork Complete } \\
\text { N/A } \\
\text { Cog. Engineer Signature \& Date }\end{array}$ & \multicolumn{2}{|c|}{$\begin{array}{l}\text { 11d. Restored to original Condi- } \\
\text { tion (Tellp. or Standby ECW only) } \\
\text { N/A } \\
\text { Cog. Engineer Signature \& Date }\end{array}$} \\
\hline \multicolumn{4}{|c|}{$\begin{array}{l}\text { 12. Deseription of chenge } \\
\text { This ECN incorporates revisions to the Light Duty Utility Arm End Effector Design } \\
\text { Criteria. }\end{array}$} \\
\hline $\begin{array}{l}\text { 13a. Justification (mark } \\
\text { Criterio Chenge [X] } \\
\text { As-Found }\end{array}$ & $\begin{array}{lll}\text { Design Improvement } & \text { [] } & \text { Environiment } \\
\text { Fecilitate Const } & {[]} & \text { Conat. Erro }\end{array}$ & $\begin{array}{lll} & {[]} & \text { Facil } \\
\text { nission }[] & \text { Desi. }\end{array}$ & $\begin{array}{ll}\text { Y Deactivation } & {[]} \\
\text { Error/Cnission }\end{array}$ \\
\hline \multicolumn{4}{|c|}{$\begin{array}{l}\text { 13b. Juatification Dotails } \\
\text { This document is being revised to accurately reflect the design changes that have been } \\
\text { made over the past } 11 \text { months via design review and to include additional information. }\end{array}$} \\
\hline $\begin{array}{l}\text { 14. Distribution cinelude } \\
\text { B. A. Carteret } \\
\text { D. S. Dutt } \\
\text { G. R. Kiebe1 } \\
\text { A. F. Pardini } \\
\text { T. J. Samuel } \\
\text { LDUA Project File }\end{array}$ & $\begin{array}{l}n=1, \text { usin, and no. of copies) } \\
N 1-21 \text { (1) } \\
N 1-21 \text { (1) } \\
N 1-21 \text { (1) } \\
N 1-21 \text { (1) } \\
N 1-21 \text { (1) } \\
N 1-21 \quad(10)\end{array}$ & DATE: & 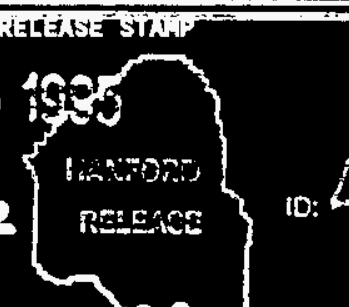 \\
\hline
\end{tabular}




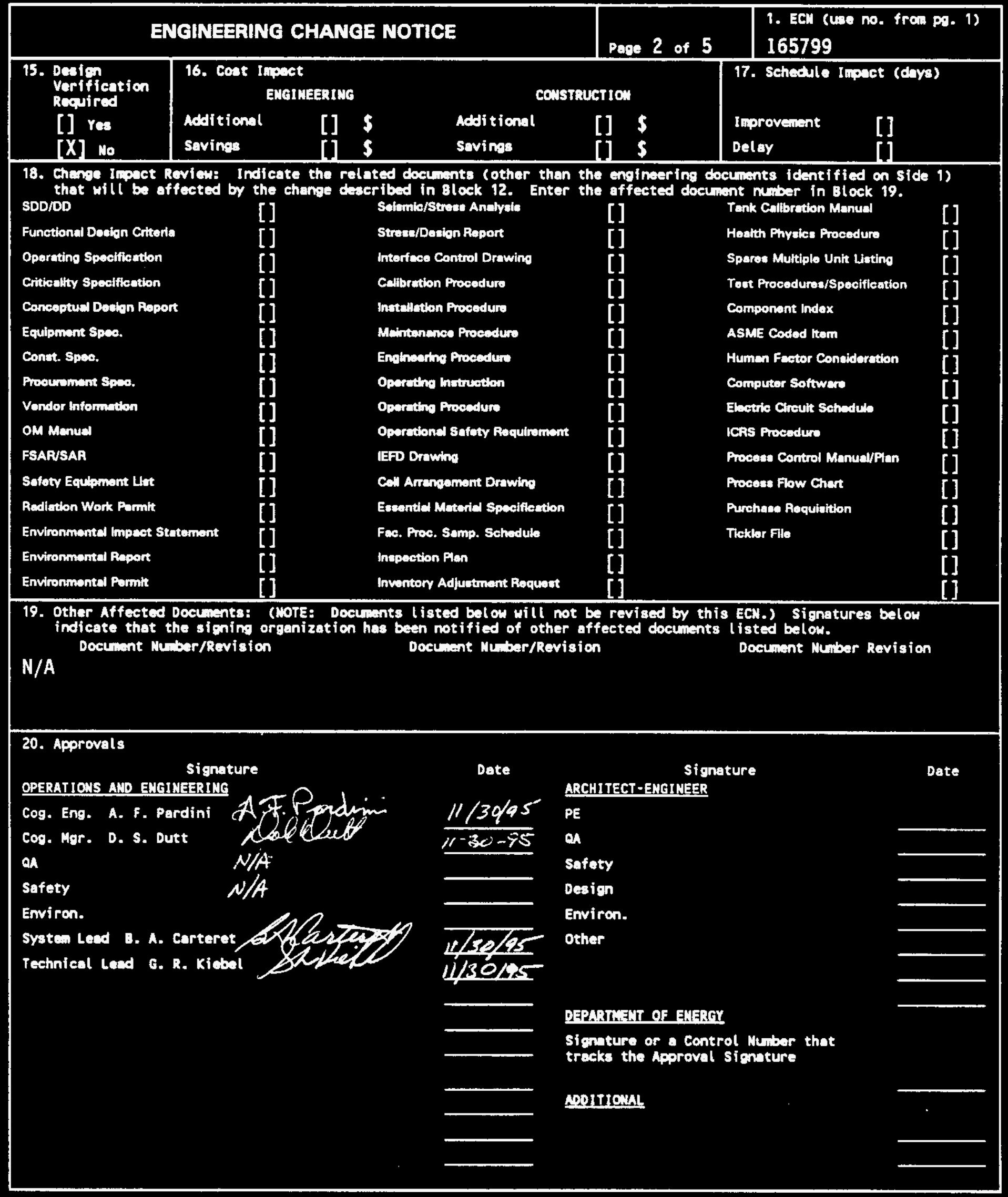


CHANGES BETWEEN REV. 0 AND REV. 1 OF

WHC-SD-TD-CR-001, "Design Criteria For

The Light Duty Utility Arm System End Effectors"

Abbreviations: Additions and deletions were made to this section to reflect changes made in other parts of the document.

Section 1.1: The nomenclature was changed from "LDUA integrated system" to "LDUA System." The reference to a specific revision of the LDUA functions and requirements document was deleted.

Section 1.2: The word "will" was changed to "shall", and the phrase "related end effector subsystems" was changed to "support equipment necessary to operate the end effector" to clarify requirements. Also, "Westinghouse Hanford Company" was added before the first use of the acronym "WHC". Other minor editorial changes were also made.

Section 1.3: Editorial changes were made in this section to reflect that fact that the names of sponsoring organizations wishing the Department of Energy have changed. Editorial changes were also made to clarify the general description of the mission of the LDUA.

Section 2.1: Editorial changes were made in this section to improve the grammar and to clarify the meaning. Also, the term "deployment vehicle" was changed to "mobile deployment system" in order to be more consistent with LDUA System nomenclature. The proper names of LDUA subsystems were capitalized.

Section 2.2: The general terminology "deployment vehicle" was changed to "Mobile Deployment System" to be more consistent with LDUA System nomenclature. Also, the erroneous description that the MDS could lower the arm into the tank was deleted - that function belongs to the Vertical Positioning Mast. A discussion of the outriggers was added.

Section 2.3: A sentence was added to this section to clarify the fact that the vertical positioning mast is provided with a housing that contains contamination. Editorial changes were made to clarify that the VPM can be included as an additional degree of freedom in LDUA resolved motion.

Section 2.4: The LDUA has no torque sensor in the shoulder - the erroneous statement that it does was deleted.

Section 2.5: Editorial changes were made to this section to improve the readability and clarity.

Section 2.6: Editorial changes were made in this section to improve the readability and to provide more detail about the TIP. Also a reference was added to the new end effector appendix.

Section 2.7: Editorial changes were made to this section to improve the readability and clarity. 
Section 2.8: A new section was added which describes the At-Tank Instrument Enclosure.

Section 2.9: When a new section 2.8 was added, the original section 2.8 became section 2.9 , and it was changed to apply to the Operations control Trailer rather than the Operations Control Center. The section header was reworded to reflect the change. The section itself was reworded to improve clarity, and new words were added to explain that the Operations Control Trailer provides physical mounting and power for subsystem electronics.

Section 2.10: This is a new section that was added to provide a general description of end effectors.

Section 3.0: Many editorial changes were made to this section to improve the readability and to correct some parts of the operating scenario that have changed since the previous version of the document. Also, subsection headers were added to separate the section into setup, operations, and takedown activities.

Section 4.0: A reference was added to the fact that some parts of the end effector support equipment may be located in the At-Tank Instrument Enclosure (ATIE). Other minor editorial changes were made to improve the readability.

Section 4.1: A reference to Tables 1 and 2 was added to this section to clarify that that is where the detailed requirements are to be found.

Section 4.1.1: The section header was changed to make it more self-explanatory.

Section 4.1.2: The section header was changed to be only a table header, and the title was changed to make it more self-explanatory.

Section 4.2.1: This section was reworded to clarify that the safety factors for yield and ultimate strength were to be chosen to provide the most conservative design.

Section 4.2.3: Editorial changes were made to be more consistent in terminology for LDUA deployed and independently deployed end effectors. A reference was added to Appendix $A$ as the source of exact end effector to TIP mechanical interface dimensions.

Section 4.2.4: An editorial change was made in this section to clarify under what conditions the end effector weight should be 1 imited to 50 pounds. A sentence was added explaining that the Tool Interface Plate has features for lifting and carrying end effectors. A reference to the new TIP appendix was also added. Wording was changed for the sake of more consistent terminology in referring to LDUA deployed end effectors

Section 4.2.5: The title of this section was changed from "End Effector Riser Loading" to "End Effector Riser Interface". Requirements were added that addressed the additional requirements for riser interfaces beyond the weight loading limits.

Section 4.2.12: The nominal flow rate for decon water supply was added to this section. 
Section 4.3.1: A reference to Appendix $B$ was added to this section with an explanation that it contained further requirements for the purge system.

Section 4.3.3: This section was expanded to apply to outdoor electrical cables as well as electrical enclosures. The section header was changed accordingly.

Section 4.3.3: This section was expanded to provide guidelines for how end effector support equipment was expected to integrate with the LDUA System.

Section 4.3.5: The table listing the TIP utilities was deleted from this section and moved to the new Appendix that describes the details of the TIP. The introductory paragraph was reworded to provide a general description of the utilities and a reference to the new Appendix.

Section 4.3.6: This section was deleted because it was mostly redundant to section 2.6 and because it did not belong in the electrical section.

Section 4.3.6: A new section added to describe the Fiber Optic Umbilical Cable (re-using the section number from the original 4.3.6 which was deleted).

Section 4.3.7: This section was added. It describes criteria for interfacing the end effector and its support equipment to the Supervisory Data Acquisition System (SDAS).

Section 4.4: A sentence was added to explain that IEEE software engineering standards were an acceptable (with WHC approval) alternative to the ones required by the LDUA software development plan.

Section 5.2: The Hanford welding standard for structural stainless steel was added to this section. A note was also added explaining that other standards for welding structural stainless steel might be acceptable with written approval by WHC.

Appendix A: This appendix was added to provide details about the Tool Interface Plate (TIP)

Appendix B: This appendix was added to provide details of the LDUA purge system and how an end effector is expected to integrate with it. 


\title{
Design Criteria for the Light Duty Utility Arm System End Effectors
}

\author{
A. F. Pardini \\ G. R. Kiebel \\ Westinghouse Hanford Company, Richland, WA 99352 \\ U.S. Department of Energy Contract DE-AC06-87RL10930
}

$\begin{array}{lll}\text { EDT/ECN: } & 165799 & \text { UC: } 2060 \\ \text { Org Code: } & 84800 & \text { Charge Code: H1E02 } \\ \text { B\&R Code: } & \text { EW4010000 } & \text { Total Pages: } 3637 \text { Scp } 1 / 18 / 95\end{array}$

Key Words: Design Criteria, Light Duty Utility Arm (LDUA), End Effectors

Abstract: The purpose of this document is to provide criteria for the design of end effectors that will be used as part of the Light Duty Utility Arm (LDUA) Systen. Actual component design, fabrication, testing, and inspection will be performed by various DOE laboratories, industry, and academia. This document augments WHC-SD-TD-FRD-003, "Functions and Requirements for the Light Duty Utility Arm Integrated System" (F\&R). All requirements dictated in the F\&R shall also be applicable in this document. Whenever conflicts arise between this document and the F\&R, this document shall take precedence.

TRADEMARK DISCLAIMER. Reference herein to any specific cormercial product, process, or service by trade nawa, tradenark, manufacturer, or otherwise, does not necessarily constitute or imply its endorseasent, recolbindation, or favoring by the United states Government or any agency thereof or its contrectors or subcontractors.

Printed in the United states of Miarice. To obtain copies of this docunent, contact: WHC/BCS Docunent Control Sarvices, P.0. Box 1970, Mailstop H6-08, Richlend UA 99357. Phone (5092) 372-21,20:. Fax (509) 376-4989.
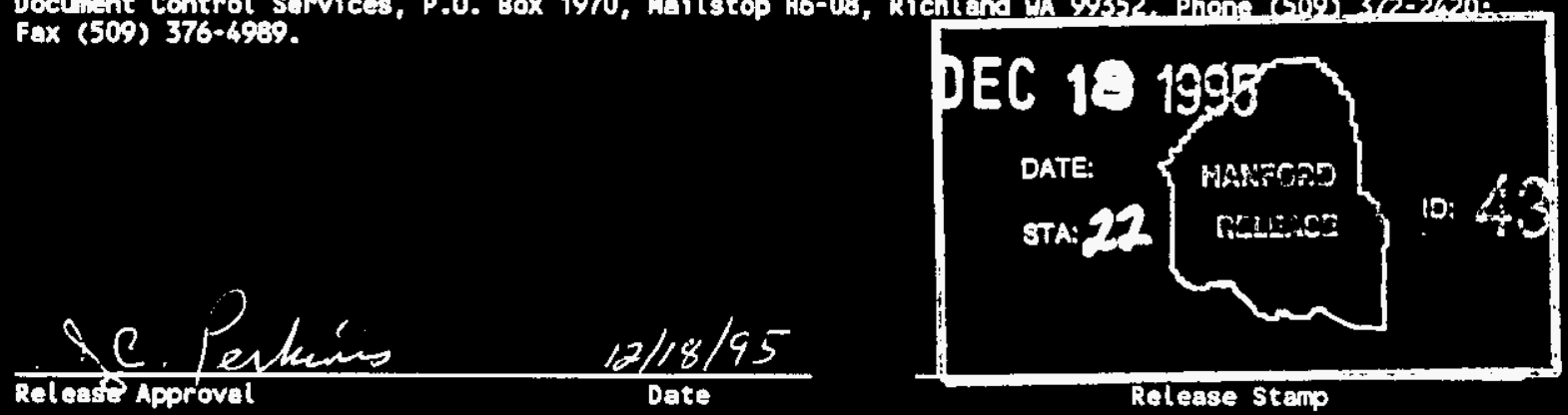

Release Stanp 
(2) Title

Design Criteria for the Light Duty Utility Arm System End Effectors CHANGE CONTROL RECORD

\begin{tabular}{|l|l|}
\hline (3) Revision & (4) Description of Change - Replace, Add, and Delete Pages \\
\hline & (7) \\
\hline RS 1 & $\begin{array}{l}\text { Total revision of WHC-SD-TD-CR-001 per ECN } \\
165799\end{array}$ \\
\hline
\end{tabular}

\begin{tabular}{l|ll} 
(5) Cog. Engr. & (6) Cog. Mgr. Date
\end{tabular}

AF Pardinifî DS, Dutt
GR Kiebel \&

\begin{tabular}{|l|l|}
\hline & \\
\hline &
\end{tabular}

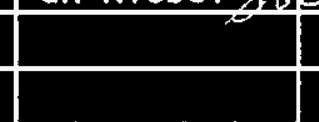

\begin{tabular}{|l|l|}
\hline & \\
\hline & \\
\hline &
\end{tabular}


DESIEN CRITERIA FOR THE LIGHT DUTY

UTILITY ARI SYSTEM END EFFECTORS

TABLE OF CONTENTS

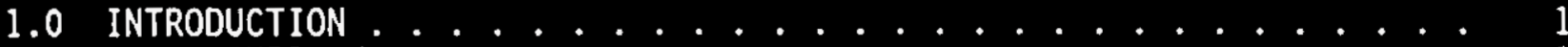

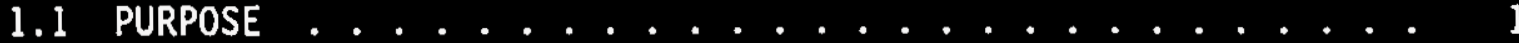

1.2 SCOPE $\ldots \ldots \ldots \ldots \ldots 1$

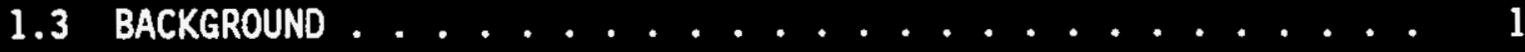

2.0 LDUA SYSTEM DESCRIPTION . . . . . . . . . . . . 2

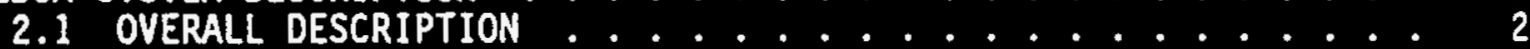

2.2 MOBILE DEPLOYMENT SYSTEM . . . . . . . . ..... 3

2.3 VERTICAL POSITIONING MAST ................ 3

2.4 LIGHT DUTY UTILITY ARM . . . . . . . . . . 3

2.5 TANK RISER INTERFACE AND CONFINEMENT . . . . . . . . 3

2.6 TOOL INTERFACE PLATE . . ........... 4

2.7 CONTROL AND DATA ACQUISITION SYSTEM . . . . . . . 4

2.8 AT-TANK INSTRUMENT ENCLOSURE (ATIE) . . . . . . . 5

2.9 OPERATIONS CONTROL ................. 5

2.10 END EFFECTORS ................ 5

3.0 LDUA OPERATING SCENARIO $\ldots \ldots \ldots \ldots$

3.1 LDUA SETUP ................. 5

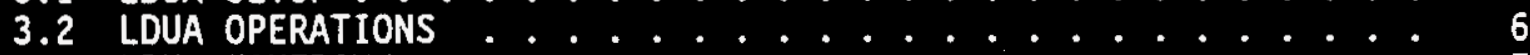

3.3 LDUA TAKEDOWN ..................... 7

4.0 END EFFECTOR DESIGN CRITERIA . . . . . . . . . . . 7

4.1 ENVIRONMENTAL DESIGN CRITERIA . * * * * . . . 7

4.1.1 TABLE 1 - In-Tank Environmental Conditions . . . 7

4.1.2 TABLE 2 - External (Out of Tank) Environmental $\ldots .8$

4.1 .3 storage .................. . . 9

4.2 MECHANICAL DESIGN CRITERIA ............. 9

4.2.1 Safety Factors .............. 9

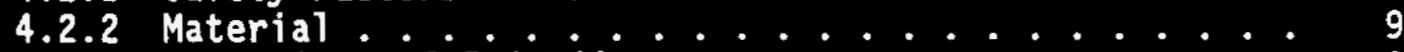

4.2.3 Dimensions of End Effectors ........... 9

4.2.4 End Effector Weight Limits ........... 9

4.2.5 End Effector Riser Interface .......... 10

4.2.6 End Effector Design Life ........... 10

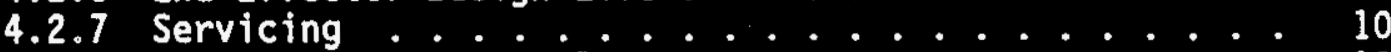

4.2 .8 Contanination Control ............ 10

4.2.9 Maintenance .............. 10

4.2.10 Lubricants .............. 11

4.2.11 Actuation ...................... 11

4.2.12 Decontamination ............ 11

4.3 ELECTRICAL DESIGN CRITERIA ............. 11

4.3.1 Electrical Design ............. 11

4.3.2 Electrical Enclosures and Cables.......... 11

4.3.3 Electrical Equipment and Wiring ........ 12

4.3.4 Power Loss ............... 12

4.3.5 Available Tip Utilities .......... 13

4.3.6 Fiber Optic Unbilical Cable ........ 13 
I 4.3.7 Supervisory Data Acquisition System Interface .... 13 4.4 SOFTWARE DESIGN CRITERIA ......................... 14

5.0 APPLICABLE CODES AND STANDARDS .............. 14

5.1 MATERIALS . . . . . . . . . . . . 14

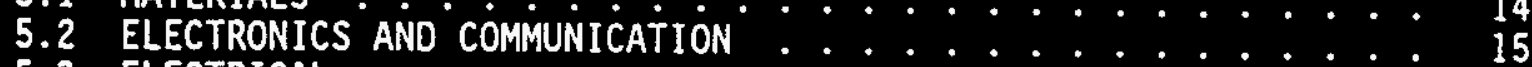

5.3 ELECTRICAL . . . . . . . . . . . . . 15

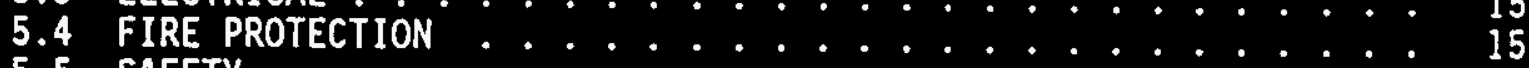

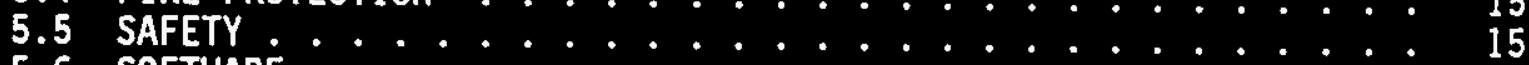

5.6 SOFTHARE $\therefore \ldots 15$

5.7 DESIGN $\ldots \ldots \ldots \ldots$

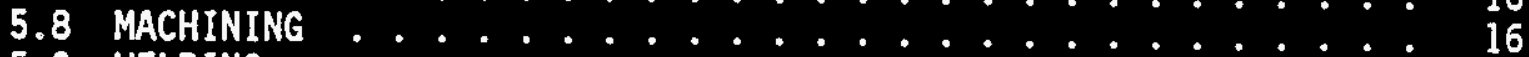

5.9 WELDING $\ldots \ldots \ldots$

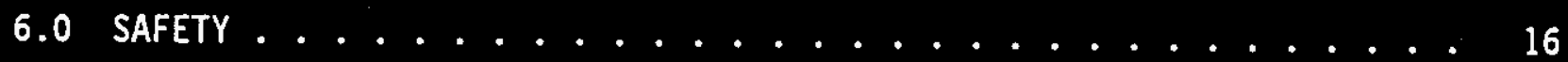

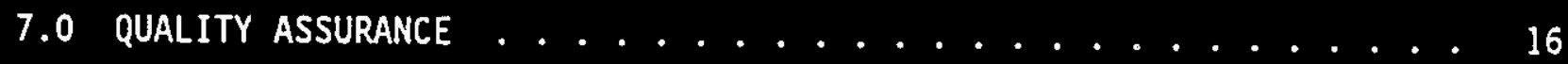

8.0 REFERENCES ........................ 17

APPENDIX A: TOOL INTERFACE PLATE DETAILS ................ 18

APPENDIX B: LDUA PURGE SYSTEM DETAILS ............. 30 
WHC-SD-TD-CR-001, REV I

\section{ABBREVIATIONS}

\begin{tabular}{|ll} 
ASME & AMERICAN SOCIETY OF MECHANICAL ENGINEERS \\
\hline ATIE & AT-TANK INSTRUMENT ENCLOSURE \\
DOE & DEPARTMENT OF ENERGY \\
\hline EE & END EFFECTOR \\
EEES & END EFFECTOR EXCHANGE SYSTEM \\
FO & FIBER OPTIC \\
I/O & INPUT/OUTPUT \\
LOUA & LIEHT DUTY UTILITY ARM \\
MDS & MOBILE DEPLOYMENT SYSTEM \\
MUX & MULTIPLEXOR \\
OCT & OPERATIONS CONTROL TRAILER \\
QAPP & QUALITY ASSURANCE PROGRAM PLAN \\
SCS & SUPERVISORY CONTROL SYSTEM \\
SDAS & SUPERVIORY DATA ACQUISITION SYSTEM \\
TFA & TANK FOCUS AREA \\
TIP & TOOL INTERFACE PLATE \\
TCP/IP & TRANSMISSION CONTROL PROTOCOL/INTERNET PROTOCOL \\
TRIC & TANK RISER INTERFACE AND CONFINEMENT \\
VAC & VOLTS, ALTERNATING CURRENT \\
VME & VERSA MODULE EUROCARD \\
VPM & VERTICAL POSITIONING MAST \\
WHC & WESTINGHOUSE HANFORD COMPANY \\
&
\end{tabular}




\section{ST is a trademark of AT\&T}

OPTOMUX is a trademark of OPTO22 corp.

Labview is a trademark of National Instruments Corp.

SPARCSTATION is a trademark of Sun Microsystems, Inc.

Solaris is a trademark of Sunfoft Inc.

Hypertronics is a trademark of Hypertronics Corp.

Tefion is a trademark of E.I. duPont de Nemours \& Co.

Parker-Hannifin coupling is a trademark of Parker-Hannifin Co. 


\section{DESIEN CRITERIA FOR THE LIGHT DUTY \\ UTILITY ARH SYSTEM END EFFECTORS}

\subsection{INTRODUCTION}

\subsection{PURPOSE}

The purpose of this document is to provide criteria for the design of end effectors that will be used as part of the Light Duty Utility Arm (LDUA) System. Actual component design, fabrication, testing, and inspection will be performed by various DOE laboratories, industry, and academia. This document augments WHC-SD-TD-FRD-003, "Functions and Requirements for the light Duty Utility Arm Integrated System" (F\&R). All requirements dictated in the F\&R shall also be applicable in this document. Whenever conflicts arise between this document and the F\&R, this document shall take precedence.

\subsection{SCOPE}

The criteria specified in this document shall apply to all end effector systems being developed for use on or with the LDUA System at the Hanford site. This includes end effectors attached directly to the LDUA, independently deployed end effectors, and all support equipment necessary to operate the end effector. This document shall serve as a bas is document for the mechanical, electrical, environmental, and safety aspects of end effector design. The requirements stipulated in this document are mandatory. Any deviations from the requirements shall be handled on a case by case basis and

I formally documented in accordance with Westinghouse Hanford Company (WHC) engineering practices. End effectors that are being specifically developed

I for use at other DOE sites shall have separate functions and requirements that may lessen the requirements of this document that are not applicable, such as radiation or environmental requirements.

\subsection{BACKGROUND}

The United States Department of Energy (DOE) created the Office of Science and Technology (OST) to assist in the environmental restoration of waste sites across the DOE complex. To complete this task, major development i efforts were initiated. One such effort is the Tanks Focus Area (TFA). This program is concentrating on the remediation of waste tanks, and is funding the development of a Light Duty Utility Arm system.

The LDUA System will be used primarily to deploy surveillance, inspection, and analysis end effectors into single shell waste storage tanks. The types of end effectors to be deployed include temperature and moisture sensors, chemical speciation probes, viewing systems, topographical mapping systems, waste sampling tools, and small scale retrieval tools. End effectors will be developed by DOE laboratories, industry, and academia. 


\subsection{LDUA SYSTEM DESCRIPTION}

\subsection{OVERALL DESCRIPTION}

The LDUA System consists of the Mobile Deployment System (MDS), the Vertical Positioning Mast (VPM), the Light Duty Utility Arm (LDUA) (with Tool Interface Plate), the Tank Riser Interface and Confinement (TRIC) System, the control and data acquisition system, the Operations Control Trailer (OCT), a complement of end effectors, and miscellaneous ancillary equipment. An illustration of the overal1 system is shown in Figure 1 .

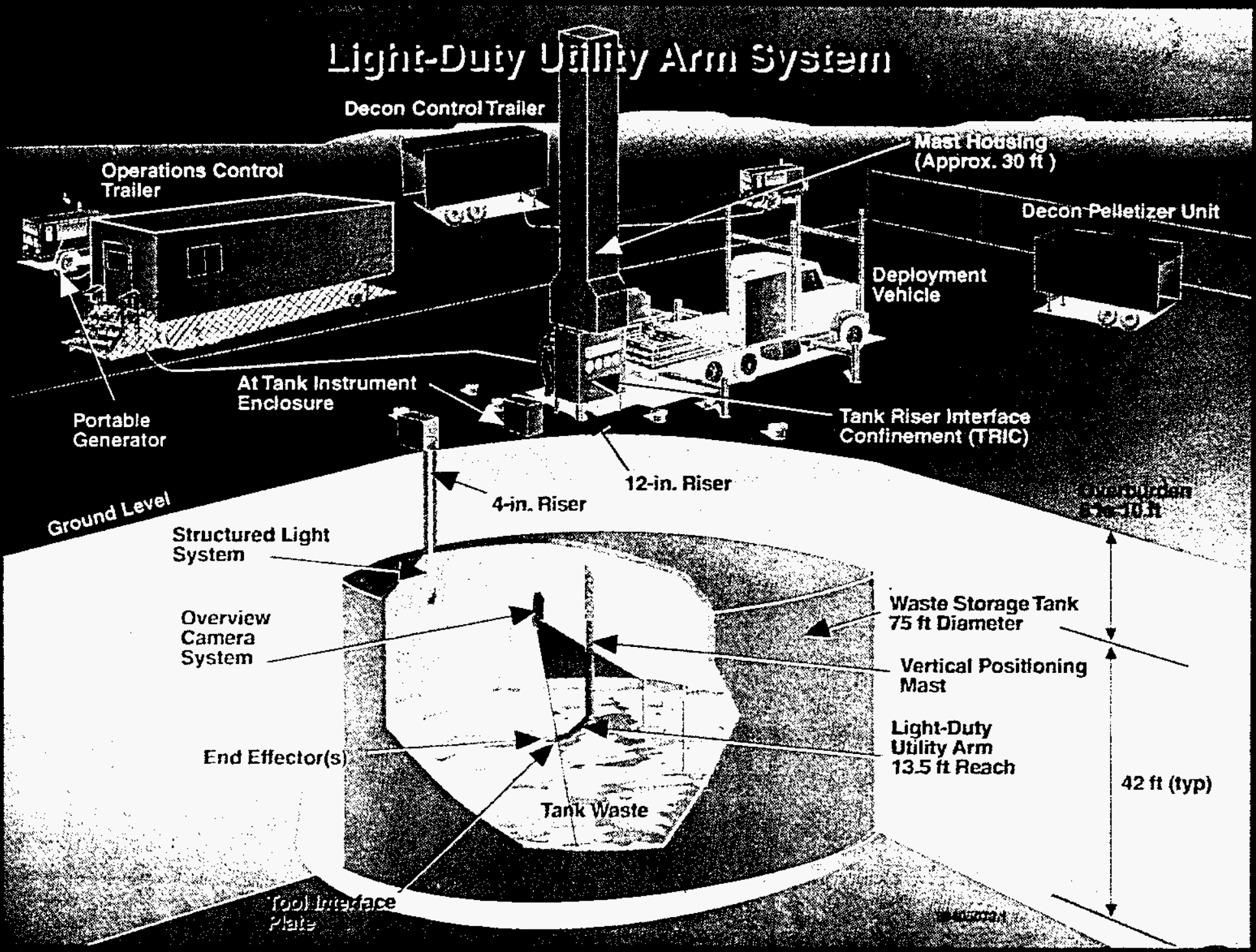

Figure 1 Light Duty Utility Arm System 


\subsection{MOBILE DEPLOYHENT SYSTEN}

The Mobile Deployment System (MDS) is a motorized vehicle that transports the LDUA assembly to the various waste tanks for deployment. It has the capability to 1) transport the LDUA system to the tank location, 2) extend outriggers, 3 ) upend the LDUA and Vertical Positioning Mast (VPM), and 4) position the VPM housing over the tank riser. Deployment operations 3 and 4 can be performed using the control pendant attached to the MDS.

\subsection{VERTICAL POSITIONING MAST}

The Vertical Positioning Mast (VPM) provides the gross vertical positioning of the LDUA within the waste tank. It may be operated independentiy from the LDUA, or may be coordinated with the LDUA as an additional degree of freedom in LDUA resolved motion. It will have infinite speed control from zero up to a maximum velocity of between 15 feet per minute and 20 feet per minute. The VPM is contained in a housing that maintains a contamination control boundary during transport and deployment.

\subsection{LIGHT DUTY UTILITY ARM}

The LDUA is a robotic manipulator that positions and orients the end effector within its working envelope. The LDUA has seven degrees of freedom that provide dexterity to reach beyond obstructions. The working envelope of the LDUA extends out to 9 feet from the centerline of the VPM. It has a maximum reach from the shoulder pitch joint to the end effector of 13.5 feet when fully extended. The operator may control the LOUA in either joint mode or cartesian mode (resolved motion) using infinitely variable speed control to allow precise placenent of end effectors during operation. The LDUA is designed to carry a nominal payload of 50 pounds and a maximum payload of 75 pounds. The center of gravity of the payload may not cause the moment at the mating surface of the Tool Interface Plate to exceed 1000 inch-pounds nor cause the moment about the wrist roll axis to exceed 150 in-pounds. At nominal payload, the LDUA has a maximum positioning error of plus or minus 0.5 inches and a repeatability of 0.2 inches or better. The position sensors in the LDUA provide a resolution of 0.05 inches or better. A six axis force/torque sensor is provided in the LDUA's wrist joint. The control system is designed to compensate for static deflection of the VPM under load in order to minimize the end-to-end error of the systen.

\subsection{TANK RISER INTERFACE AND CONFINEMENT}

The Tank Riser Interface and Confinement (TRIC) provides an interface between the LDUA system and the waste tank riser. It is used for change-out of end effectors, minor maintenance tasks, and containment of the tank atmosphere. A decontamination system is included for the gross decontamination of the VPM, LDUA, and deployed end effectors to levels acceptable for on-site transportation of the LDUA System. 


\subsection{TOOL INTERFACE PLATE}

The Tool Interface Plate (TIP) provides a standardized mounting mechanism common to each of the end effectors that are carried on the LDUA. It consists of two plates, with the master plate located on the wrist of the LDUA, and a slave plate located on each end effector. A seal is provided near the outside diameter of the TIP to seal the interface joint between the plates against the tank atmosphere and contents. The TIP has a set of guide pins that assure proper alignment of the two halves and there are three latches that lock the TIP halves together. The latching mechanisms are each secured by rotating a locking cam one-half turn (using a tool with a standard socket drive). Ail of the utilities required for end effector operation are routed within the sealed diameter of the TIP. The utilities include common electrical power, instrumentation and control, and fluid (gas and liquid) lines. The TIP master and slave plates are designed and fabricated by the LDUA developer. A TIP slave plate for each end effector will be furnished by WHC to the end effector provider. Details of the TIP are provided in Appendix A

\subsection{CONTROL AND DATA ACQUISITION SYSTEM}

The LDUA control and data acquisition system has a supervisory level and a subsystem level. The subsystem level is concerned with the basic operation of the LDUA subsystems. Each subsystem has its own controller that can support all the fundamental operations of the subsystem. This controller can be simple or sophisticated, depending on the nature of the subsystem. The supervisory level is concerned with centralization of control and data acquisition functions and with coordinated operation between subsystems. Supervisory operations are all conducted from the Operations and Control Trailer (OCT). End effector subsystems and the TRIC are interfaced with the Supervisory Data Acquisition System (SDAS). The LDUA Subsystem Controller is interfaced with the Supervisory Control System (SCS).

The LDUA Subsystem Controller provides the LDUA Console in the OCT for operator control of the LDUA, VPM, and MDS. The Supervisory Control Subsystem provides a 3D graphic display for monitoring LDUA and VPM motion. This display allows all motion of the LDUA and VPM to be previewed against a model of operating environment that defines safe operating areas. LDUA and VPM motion is checked for collisions. If the previewed motion is collision-free, the operator may command the motion to execute.

The Supervisory Data Acquisition Subsystem is able to acquire, process, display, and store data from the end effector subsystem controllers and can tag this stored information with information such as the identity of the operator, identity of the tank and riser of deployment, and position of the LDUA when it was taken.

The Supervisory Data Acquisition Subsystem also provides a means of displaying and recording video information from the end effectors and observational video cameras. The capability to overlay titles and other selected information onto the video is also provided.

Since several end effectors share a single set of TIP utilities, a means is provided to manually switch the TIP utilities to the appropriate at-tank 
support electronics to match the end effector mounted on the TIP.

\subsection{AT-TANK INSTRUNENT ENCLOSURE (ATIE)}

The At-Tank Instrument Enclosure houses end effector support electronics that must be near the end effector (the ATIE is located within 50 feet of the MDS). This enclosure is weather tight with heating and cooling to maintain internal temperature between 50 and 95 degrees fahrenheit during operation. Standard Electronic Industrial Association (EIA) 19-inch racks are provided for mounting of end effector support equipment. Standard 110 VAC power is provided for equipment.

\subsection{OPERATIONS CONTROL TRAILER}

The Operations Control Trailer (OCT) is the command center for the LDUA system. It houses both the equipment and personnel to remotely operate the LDUA System. The OCT will be located outside the tank farm perimeter fence in a non-contaminated area and it can be up to 900 feet away from the LDUA. Standard Electronic Industrial Association (EIA) 19-inch racks are provided for mounting of end effector support equipment. Standard 110 VAC power is provided for equipment. Fiber Optic (FO) Umbilical Cables connect the Operations Control Trailer to the At-Tank Instrument Enclosure.

\subsection{END EFFECTORS}

End effectors are the tools that accomplish the specific in-tank tasks that the LDUA System performs. There are two types of end effectors, LDUA deploved end effectors and independently deployed end effectors. LDUA deployed end effectors are TIP mounted on the end of the LDUA. Independently deployed end effectors enter the tank through other risers (usually 4 inch risers) and provide their own riser interface equipment. The criteria in this document are assumed to apply to both types of end effector unless specifically noted.

\subsection{LDUA OPERATING SCENARIO}

\subsection{LDUA SETUP}

When a tank has been identified for inspection, plug gages will be used to verify that the risers chosen for deployment are adequately plumb and have adequate internal clearance for the LDUA deployed and independently deployed end effectors.

Following successful riser gaging, the major equipment systems of the LDUA System will be transported to the tank farm and set up. The Operations Control Trailer (OCT) will be placed outside the tank farti fence. The At-Tank Instrument Enclosure (ATIE) will be placed in the vicinity of the riser chosen for LDUA deployment. The Fiber Optic (FO) Umbilical Cable will be connected between the ATIE and the OCT. The Power Distribution Skid will be placed inside the tank farm near the other equipment and power cables will be connected between it and the main source of 480 VAC (either a portable generator or a temporary substation). Power cables will also be connected 
between the Power Distribution Skid and the ATIE, and between the OCT and the main power source.

Independently deployed end effector systems will be attached to the risers (typically 4 inch) chosen for their deployment. These systems will have their own riser interface and environmental containment and any necessary local support electronics. They will be connected to the ATIE and will be operated from the OCT.

The Tank Riser Interface and Confinement (TRIC) subsystem will be attached to the riser chosen for deployment of the LDUA. It's decontamination module will be connected to the Decon Water Supply Systen.

The LDUA system will be transported to the tank using the Mobile Deployment System (MDS). The MDS will be positioned near the TRIC, and will be connected to the Power Distribution Skid so that its hydraulics can be powered up. The MDS outriggers will be extended and locked to provide a firm base for LDUA deployment. The control pendant attached to the MDS will be used to upend, position, and align the Vertical Positioning Mast (VPM) housing to mate with the TRIC. A contamination control boundary will be established between the TRIC and the VPM housing using a flexible seal. The tank pressure sense line for the purge system will be connected between the TRIC and the MDS. With the mating to the TRIC complete, the MDS umbilical will be connected to the ATIE and full control will be transferred to the LDUA Console and Supervisory Control System (SCS) inside the OCT. An optical alignment end effector will be used to finalize the position of the VPM housing to insure that the VPM and LDUA are accurately aligned with the riser to provide a clear path for entering the tank.

\subsection{LDUA OPERATIONS}

To initiate a surveillance, inspection, or characterization campaign, an end-effector will be selected for the desired operation. The installation of the end effector to the LDUA will be accomplished within the TRIC, utilizing a tool change-out mechanism to assist the operator in positioning the end effector and attaching it to the LDUA. Following end effector attachment, the VPM, LDUA, and end effector will be lowered through the TRIC and the decontamination system and into the tank through the tank riser. These operations will usually be performed using the supervisory controller; however, the MDS control pendant can provide simple operation of LDUA and VPM for recovery or maintenance activities.

Operation of the LOUA and end effectors inside the waste tank will normally be performed from the Operations Control Trailer using supervisory control (automated sequences) or by tele-operation (human in the 10op) using graphic computer displays to monitor and control the equipment, and on-board and overview cameras to provide direct visual feedback to the operator. After lowering the VPM to the desired elevation in the tank, the LDUA will position end effectors to perform their in-tank functions. End effectors will normally be operated from the Operations Control Trailer using the Supervisory Data Acquisition System, which will also collect the data they generate. It is anticipated that the system will operate at the tank for approximately one to two weeks. During this period, multiple end effector change-outs may be performed without removing the VPM housing from the TRIC. Gross 
decontamination of the VPM, LDUA and end effectors will take place during these exchanges as the VPM is withdrawn through the decontamination module. It is expected that the LDUA and VPM will be retracted into the VPM housing during the off shift and will be moved to the area of lowest radiation level inside tank when not busy.

\subsection{LDUA TAKEDONY}

When in-tank operations have been completed, the end effector will be dismounted from the LDUA and the VPM and LDUA will be retracted into the VPM housing. The VPM housing will be sealed to contain any residual contamination on the VPM and LDUA before it is detached from the TRIC. The VPM housing will then be lowered to the horizontal position on the MDS for storage and transport. The independently deployed end effector systems will be recovered from the tank and their equipment secured for transport. The TRIC will be removed from the riser and the riser will be closed. The umbilical and power cables between the Power Distribution Skid, the ATIE and the OCT will be disconnected and recovered, and the ATIE and OCT made ready for transport.

\subsection{END EFFECTOR DESIGN CRITERIA}

Complete end effector systems shall be provided that include the in-tank head assembly, umbilical cabling, at-tank instruments and enclosures, control and display electronics, and operating and display software. Components of these systems will be located in various areas including in-tank, above ground (outside), in the ATIE, and in the OCT.

\subsection{ENVIROWHENTAL DESTGN CRITERIA}

End effector systems shall be capable of normal operation in the environmental conditions given in Tables 1 and 2:

\subsubsection{TABLE 1 - In-Tank Environinental Conditions}

\begin{tabular}{|l|l|}
\hline Ambient Temperature & $\begin{array}{l}\text { Normal operation in a temperature range from }+50 \\
\text { degrees Fahrenheit to }+150 \text { degrees Fahrenheit. }\end{array}$ \\
\hline Relative Humidity & $\begin{array}{l}\text { Normal operation in a humidity range from } 10 \% \text { to } \\
100 \% .\end{array}$ \\
\hline Pressure & $\begin{array}{l}\text { Normal operation within a pressure range of } \pm 7 \\
\text { inches of water. }\end{array}$ \\
\hline Dust & $\begin{array}{l}\text { Normal operation within an environment that may } \\
\text { contain abrasive dust in the tank vapor space. }\end{array}$ \\
\hline Chemical & $\begin{array}{l}\text { Normal operation in a chemical environment that } \\
\text { varies from that of concentrated nitric acid fumes } \\
\text { to waste material whose pH approaches } 14 .\end{array}$ \\
\hline
\end{tabular}




\begin{tabular}{|l|l||}
\hline Vapors & $\begin{array}{l}\text { Tanks may contain an explosive atmosphere and will } \\
\text { require design to section } 4.3 .1 \text { of this document. }\end{array}$ \\
\hline Radiation & $\begin{array}{l}\text { Normal operation in a radiation field of } 2000 \\
\text { rad/hour, for equipment that operates in close } \\
\text { proximity (< } 3 \text { feet) to the waste surface; or in a } \\
\text { radiation field of } 1000 \text { rad/hour, for equipment that } \\
\text { operates in the vapor space ( } 3 \text { feet) above the } \\
\text { waste surface. Equipment must be capable of } \\
\text { operating properly, without significant degradation } \\
\text { in performance, until a minimum accumulated dose of } \\
1 \times 10^{8} \text { is attained. For equipment with an } \\
\text { inherently low tolerance for radiation, a minimum } \\
\text { accumulated dose of } 1 \text { X 10 may be acceptable, if } \\
\text { change-out of the equipment is sufficiently easy. } \\
\text { Radiation cumulative dose requirements may be met by } \\
\text { periodic modular replacement of radiation } \\
\text { susceptible components. }\end{array}$ \\
\hline
\end{tabular}

\subsubsection{TABLE 2 - External (Out of Tank) Environmental Conditions}

\begin{tabular}{|l|l|}
\hline Ambient Temperature & $\begin{array}{l}\text { Normal operation in a temperature range from }-20 \\
\text { degrees Fahrenheit to }+120 \text { degrees Fahrenheit and } \\
\text { shall tolerate additional heat loads result ing from } \\
\text { operation in direct sunlight. }\end{array}$ \\
\hline Relative Humidity & $\begin{array}{l}\text { Normal operation in a humidity range from 4\% to } \\
100 \% .\end{array}$ \\
\hline Wind & $\begin{array}{l}\text { Normal operation in wind speeds of up to } 40 \text { miles } \\
\text { per hour. In addition, the end effector systems } \\
\text { shall be able to withstand, without damage, wind } \\
\text { speeds up to } 80 \text { miles per hour. }\end{array}$ \\
\hline Moisture & $\begin{array}{l}\text { Normal operat ion in external rain environments with } \\
\text { rainfalls at the rate of up to } 2 \text { inches per hour } \\
\text { and snow environments with snowfall accumulations } \\
\text { of up to 2 feet. }\end{array}$ \\
\hline Dust & $\begin{array}{l}\text { Normal operation in an environment which has } \\
\text { periodic severe dust storms. }\end{array}$ \\
\hline Topography & $\begin{array}{l}\text { All tank farm equipment must be able to operate (or } \\
\text { be leveled to operate) on terraces with slopes up } \\
\text { to 10\% and berms or curbs up to } 6 \text { inches high. }\end{array}$ \\
\hline
\end{tabular}


WHC-SD-TO-CR-001, REV 1

\subsubsection{Storage}

All end effector systems shall be designed to allow for storage in outdoor containers with internal temperatures ranging from $-20 \mathrm{~F}$ to $+150 \mathrm{~F}$.

\subsection{HECHANICAL DESIEN CRITERIA}

\subsubsection{Safety Factors}

All load-bearing components shall be designed with a five-to-one safety factor for lifting points over the ultimate strength (breaking strength). Al] other load bearing components shall be designed with a two-to-one safety factor over the ultimate strength (breaking strength) or one and one haif-toone safety factor over the yield strength, whichever is more conservative.

\subsubsection{Material}

All structural materials shall be in accordance with ASTM or ASME standards. In-tank components shall be constructed of materials resistant to the tank environment and qualified as spark resistant as much as practical to minimize the use of coatings. Suggested materials include, but are not restricted to, austenitic stainless steel or titanium alloys that have been stress relieved.

\subsubsection{Dimensions of End Effectors}

Independently deployed end effectors are restricted in diameter according to the riser being used. For 4 inch risers, the end effector shall fit within a cylindrical envelope no larger in diameter than 3.5 inches. For I 12 inch risers, the end effector shall fit within a cylindrical envelope no larger in diameter than 10.5 inches.

LDUA deployed end effectors shall fit within a cylindrical envelope no larger in diameter than 10.5 inches and no longer than 30 inches inclusive of the end effector portion of the TIP (refer to Appendix A for exact dimensions of the end effector to TIP mechanical interface).

End effectors shall be designed with smooth contours, chamfers, or leadins so that they will not easily become hung up on riser bottons and other intank components.

\subsubsection{End Effector Weight Limits}

LDUA deployed end effectors shall not weigh more than 75 pounds, including the end effector portion of the TIP. This portion of the TIP sha1) be consfdered to weigh 15 pounds for initial design purposes. Weight distribution of end effectors shall be configured to limit the moment that is applied to the mating surface between the end effector half and the LDUA half of the TIP to 1000 inch-pounds. In addition, the moment about the wrist roll axis shal1 not exceed 150 inch-pounds. For applications where it is critical to attain the repeatability and resolution requirements described in section 2.4 , the end effector shal1 not exceed the nominal payload of 50 pounds (including the end effector portion of the TIP). There is no weight restrictions on independently deployed end effectors with the exception of 
riser loading requirements in section 4.2 .5 .

A11 end effectors shall be designed for easy lifting depending on their weight. End effectors weighing more than the 1 imit for person 1 ifting shall be supplied with lifting fixtures for mechanical lifting. The Tool Interface Plate has three indentations for engaging the End Effector Exchange System. These may also be used for lifting and carrying the end effector when it is not in the process of being mounted onto or dismounted from the LDUA.

\subsubsection{End Effector Riser Interface}

Independently deployed end effectors shall provide equipment to interface the end effector to the riser. This riser interface equipment shall include provisions to mechanically attach to the riser flange, to maintain containment of the tank atmosphere, to maintain containment of contamination (while deployed and when in transport or storage). End Effector deployment systems shall not exceed the applicable riser load limits. The loading limit for 4 inch risers is 500 pounds maximum. The loading 1 imit for 12 inch risers is 3000 pounds maximum. These are axial loads with a load application point

that is not more than 8 feet above the riser flange, or offset from the center line more than 6 inches.

\subsubsection{End Effector Design Life}

Al1 end effectors shall be designed to have a usable lifetime of 5 years. The mean time between failure shall be no less than 6 months under continuous operation or until total allowable radiation dose 1 imit is reached as described in section 4.1.1. The mean time of repair shall not exceed 24 hours for any component failure or malfunction.

\subsubsection{Servicing}

End effectors shall be designed to minimize scheduled preventative maintenance. Components shall be selected or substituted where possible to reduce maintenance and increase mean time between failure. End effectors shall be designed without sharp edges, or projections which could cause injury to maintenance personnel.

\subsubsection{Contamination Control}

End effectors shall be designed and fabricated to facilitate the cleaning of contaminated surfaces. Design shall incorporate smooth surfaces and sealed segments for ease in decontamination.

\subsubsection{Maintenance}

End effectors shall be designed so the components that are most likely to fail are readily accessible and easily replaced as a unit or as a subassembly. End effectors shall be modular in design to facilitate fast repair cycles by personnel working in anti-contamination clothing. 


\subsubsection{Lubricants}

Nonvolatile, radiation resistant lubricants shall be used for in-tank components. Lubricants must be contained so that the lubricants can not leak into the tank environment.

\subsubsection{Actuation}

End effectors may use either electric or pneumatic actuation. The waste tank environment severely restricts the addition of organic compounds during operation and all possible failure modes. Actuation by hydraulics is discouraged, however if provisions are made for leakage control then hydraul ic actuation may be allowed. End effectors that use fluids for testing shall have the ability to control that fluid so that there is minimal loss to the waste tank. Methods of testing, types of fluids, and estimated losses to the waste tank shall be provided for Westinghouse Hanford Company (WHC) review and approval prior to Prel iminary Design of the end effector. Actuators for TIP mounted end effectors are 7 imited by the available utility services (see section 4.3.5).

\subsubsection{Decontamination}

End effectors shall be designed to allow for decontamination using $\mathrm{CO}_{2}$ pellets as follows:

Pellet Size

Pellet Density

Pellet Velocity

Flow rate (at nozzle)
- $1 / 8$ inch diameter by $1 / 4$ inch long

$-1.56 \mathrm{~g} / \mathrm{cm}^{3}$

- 75 to 1000 feet/second

- 450 SCFM at 250 psi

End effectors shall be designed to allow for decontamination using a water spray generated by passing 500 psi (maximum) water through a nozzle at a nominal rate of 1.5 gallons per minute.

\subsection{ELECTRICAL DESIGN CRITERIA}

\subsubsection{Electrical Design}

All electrical design, electrical equipment, electronic equipment, and wiring shall be in accordance with applicable codes and standards. All intank end effectors shall be designed to meet the requirements for qualification under the National Electric Code for Class I, Division I, Group B components. Appendix B contains further details on the LDUA purge system and requirements that the end effector must meet in order to be compatible with it.

\subsubsection{Electrical Enclosures and Cables}

Enclosures for end effector electrical systems located outside the Operations Control Trailer or outside the At-Tank Instrument Enclosure shall be National Electrical Manufacturers Assocjation (NEMA) Type 4 enclosures for outdoor locations that conform to NEMA ICS-6. Electrical cables located outside of electrical enclosures shall be rated for outdoor service per the NEC and shall be sunlight resistant and UL listed. 
Cables that are run in the ventilation ducting in the OCT (this includes the route between the external cable entrance panel and the equipment mounting racks) shall be plenum rated.

\subsubsection{Electrical Equipment and Wiring}

End effector providers shall furnish the electrical and electronic equipment and cabling necessary to operate the end effector. LDUA end effectors and their support equipment shall use the infrastructure provided by the Operations Control Trailer, At-Tank Instrument enclosure, Fiber Optic Umbilical Cable, and TIP utility services in order to integrate properly with the LDUA system. This infrastructure includes equipment mounting racks, 110 VAC power, and signal cabling.

The following list provides specific LDUA infrastructure requirements for end effectors and their support equipment to follow. All end effectors and their support equipment shal1:

1) use the ATIE and its services (see section 2.8) for:

a. mounting local support equipment

b. supplying 110 VAC power for local support equipment

c. connecting local support equipment to the Fiber optic (FO) Umbilical (via the Fo interface panel)

d. connecting to the LDUA purge system (see Appendix B).

2) use the Fiber Optic (F0) Umbilical (see section 4.3.6) for:

a. communicating between local support equipment in the ATIE and remote support equipment in the OCT

3) use the OCT (see section 2.9) for:

a. mount ing remote support equipment

b. supplying 110 VAC power for remote support equipment

c. connecting remote support equipment to the Fiber Optic (FO) Umbilical (via the Fo interface panel)

4) interface with the SDAS (see section 4.3.7)

In addition, LDUA deployed end effectors and their support equipment sha11:

5) use the LDUA utility services provided at the TIP (see section 4.3.5)

6) Use the ATIE (see section 2.8) for:

a. connecting local support equipment to LOUA utility services (via the end effector patch panel)

\subsubsection{Power Loss}

The system shall be designed such that a power surge, the loss of electrical power, or the return of lost power shall not result in damage to the end effector system. 
WHC-SD-TD-CR-001, REY I

\subsubsection{Available TIP Utilities}

Utility service lines (electrical and pneumatic) are provided in the LDUA for the end effector to use to connect to its support equipment outside the tank. The electrical service utilities include a number of signal circuits, power circuits, and coaxial cable circuits. These electrical services are carried from the TIP to the At-Tank Instrument Enclosure (ATIE) where they are made available to the end effector's support equipment by a patch panel that allows them to be manually switched among several end effectors. The three pneumatic utility service lines are carried from the TIP to quick-disconnect fittings on the exterior of the Vertical Positioning Mast (VPI) housing. One of the pneumatic lines is used for the LDUA purge system (see AppendiX B). The other two lines are available for use by the end effector support equipment. Refer to Appendix A for further details.

\subsubsection{Fiber Optic Umbilical Cable}

The Operations Control Trailer (OCT) and the At-Tank Instrument Enclosure (ATIE) are connected by a WHC furnished Fiber Optic (FO) Umbilical Cable that provides many individual fibers. This Fo umbitical carries the control and data signals from the equipment at the tank to the equipment in the OCT. End effector support electronics shall use this cable for communications between support electronics in the ATIE and OCT (appropriate copper-to-fiber conversion modules must be incorporated into the electronics). Each end effector is allocated two fibers, and more may be available with WHC approval. This umbilical is a 62.5 micron, multimode, glass fiber optic cable. Connector interface panels (using type $S T^{1}$ connectors) are provided at the ATIE and OCT. The FO Umbilical Cable terminates on one side of these interface panels. Short lengths of Fo cable (WHC furnished) connect between the interface panels and end effector support electronics chass is mounted in the OCT or ATIE equipment racks.

\subsubsection{Supervisory Data Acquisition System Interface}

The end effector subsystem controller shall integrate with the Supervisory Data Acquisition System (SDAS). It shal1 use one of the standard SDAS interfacing approaches 1 isted below. Only the basic framework of the approach is described in the 1 ist - the actual details must be resolved by discussion between the end effector provider and WHC.

a) The end effector subsystem controller may interface with an OPTOMUX ${ }^{2}$ input/output (I/0) multiplexor (MUX) in the ATIE using individual signal channels of common industrial type (0-10 VDC, $24 \mathrm{VDC}$ on/off, etc.). This approach is most applicable to end effectors that have only a few functions and that do not generate significant amounts of data. WHC would typically provide the Labview virtual instrument (VI) software for the user interface.

I ST is a trademark of AT\&T

2 opmomux is a trademark of OpTO22 corp.

3 Labview is a trademark of National Instruments Corp. 
b) The end effector subsystem controller may interface with Versa Module Eurocard (VME) I/0 cards in the OCT using individual analog, digital, or serial ASCII signal channels. WHC would prefer the use of VME cards for which there are existing SDAS driver software modules, but will consider the use of other cards. This interfacing approach is most applicable to end effectors that have more complex functions or more I/0 channels, that generate moderate amounts of data, or that find it more convenient to implement the interface in the OCT. Either WHC or the end effector supplier (or both) may be responsible for writing the Labview virtual instrument (VI) software for the user interface and the driver software modules for new VME cards.

c) The end effector subsystem controller may interface with the 10BaseT ethernet hub in the OCT and provide remote user interface software that runs on the SDAS Data Acquisition Workstation (SPARCStation $10^{4}$ running the Solaris $s^{5}$ operating system). This software would use TCP/IP protocols to communicate with the end effector subsystem controller and with the appropriate SOAS software. This approach is most applicable to end effectors that have their own on-board computer and that are highly autonomous, or that generate considerable amounts of data. WHC would typically provide the Labview virtual instrument (VI) software that would Iaunch the end effector's remote user interface software and that would read the data.

\subsection{SOFTWARE DESIEN CRITERIA}

A11 end effector system software shall be in accordance with the LDUA Software Development Plan, Westinghouse Hanford Company document WHC-SD-TDSDP-001 (IEEE software standards may be used instead with the written approva) of $W H C)$.

\subsection{APPLICABLE CODES AND STANDARDS}

Applicable codes and standards shall be used in the design of all end effectors. The most current codes, standards, and orders shall be used. End effector systems shall be designed to meet or exceed the requirements of the listed codes and standards. All reference documents 1 isted below shall be the latest revision as of January 1, 1994.

\subsection{MATERIALS}

The ASTM specification shall be documented for the 300 Series Stainless Steels and other materials that are selected for the fabrication of any component or structure in the end effector.

\footnotetext{
4 sparcstation is a trademark of sun Microsystems, Inc.

5 solaris is a trademark of sunsoft Inc.
} 


\subsection{ELECTRONICS AND CONHUNICATION}

Electronic Industrial Association

RS-232 Interface Between Data Terminal Equipment and Data

Communication Equipment Employing Serial Binary Data Interchange

RS-281 Electrical and Construction Standards for Numerical Machine Control

RS-449 General Purpose 37 Position and 9 Position Interface for Data Terminal Equipment and Data Circuit Terminating Equipment Employing Serial Binary Data Interchange.

RS-422-A

Electrical Characteristics of Balanced Voltage Digital Interface circuits

RS-423-A

Electrical characteristics of unbalanced voltage digital interface circuits

\subsection{ELECTRICAL}

National Electrical Manufacturers Association (NEMA)

ICS 1 Industrial Controls and Systems

ICS 6 Enclosures for Industrial Controls and Systems

\subsection{FIRE PROTECTION}

National Fire Protection Association (NFPA)

70

National Electric Code (NEC)

\subsection{SAFETY}

Occupational Safety and Health Administration (OSHA)

29 CFR 1910 Occupational Safety and Health Standards

\subsection{SOFTMARE}

Institute of Electrical and Electronics Engineers (IEEE)

829 IEEE Standard for Software Test Documentation

830 IEEE Guide to Software Requirements Specifications

1063 IEEE User Documentation

983 IEEE Guide for Software QA PIans

American National Standards Institute (ANSI) 
American Nuclear Society (ANS)

ANSI/ANS 10.4. Verification and validation of scientific and engineering computer programs.

\subsection{DESIEN}

ANSI Y14.5M Dimensioning and Tolerancing

SDC-1.3

Preparation and Control of Engineering and Fabrication Drawing

\subsection{MACHINTNG}

ANSI B46.1 Surface Finishes

ASA B1.1 Screw Threads

\subsection{NELDING}

American Welding Society (AWS)

AWS D1.1 Structural Welding Code for Steel

AWS A2.4 Weld Symbols

HS-V-S-0013* Welding of Structural Stainless Steel and Nickel Alloy Components

*Other standards for welding structural stainless steel may be acceptable with specific written WHC approval.

\subsection{SAFETY}

A11 aspects of safety shall be considered in the design of end effector systems. End effector designs will undergo safety analys is according to the LDUA System Safety Program Plan, WHC-SD-WM-WP-231.

\subsection{QUALITY ASSURANCE}

Quality Assurance/Control activities for all end effector providers involved in the design, fabrication, and acceptance testing shall be executed in accordance with the LDUA Quality Assurance Program P1 an (QAPP) (WHC-SD-WMQAPP-022). The QAPP shall be used to develop verification criteria in design documents, i.e., drawings, specifications, test procedures, and to define quality assurance interfaces. 


\subsection{REFERENCES}

1. WHC-SD-TD-FRD-003, Functions and Requirements for the Light Duty Utility Arm Integrated System, Westinghouse Hanford Co., Richland, Washington, 1994. (Draft)

2. WHC-SD-TD-SDP-001, Light Duty Utility Arm Software Development Plan, Westinghouse Hanford Co., Richland, Washington, 1993.

3. WHC-SD-WM-QAPP-002, Qual ity Assurance Project Plan Light Duty Utility Arm (LDUA), Westinghouse Hanford Co., Richland, Washington, 1993. 


\section{APPENDIX A: TOOL INTERFACE PLATE DETAILS}

This appendix contains a table and several figures that provide details about mounting end effector to the Tool Interface Plate (TIP) and about using the utility services that are available at the TIP. to the TIP:

Figures A-1 through A-3 show some details of mounting the end effector

- Figure A-1 is a cross section view of the two TIP halves showing end effector attachment arrangements.

- Figure A-2 is a top view of the TIP showing the locations of the countersunk access holes for the end effector mounting screws.

- Figure A-3 is drilling guide for the surfaces of the end effector that attach to the TIP, showing the location and sizes of the holes for the mounting screws and dowel pins.

Figures A-4 through A-10 show details of the utility services and how the interface to them is made.

- Table A-1 lists the TIP utility services that are provided to the end effector via the TIP.

- Figure A-4 is a top view of the TIP showing the placement of the utility services connectors and the arrangement of inserts in the Hypertronics ${ }^{6}$ electrical connectors.

- Figure A-5 is a block diagram of the end effector utility services showing how they are organized and routed between the TIP and the end effector support electronics. Approximate cable lengths are noted.

- Figures A-6 through A-10 show the detailed interface wiring information for the utility services electrical circuits.

6 Hypertronics is a trademark of Hypertronics Corp. 
TABLE A-1 END EFFECTOR UTILITY SERVICES

\begin{tabular}{|c|c|c|c|}
\hline D. & 4. OS CONOUCTORS & (1): S1 & commins \\
\hline Electrical & 12 & 16 AWG (16 Pins) & $\begin{array}{l}4 \text { Shielded } \\
\text { Triplets }\end{array}$ \\
\hline Signal & 60 & 22 AWG (90 Pins) & $\begin{array}{l}\text { Twisted/Shielded } \\
\text { ( } 30 \text { pair) }\end{array}$ \\
\hline Coaxial & 2 & 75 Ohm RG-59U & $\begin{array}{l}\text { Coaxial Pin } \\
\text { Connector }\end{array}$ \\
\hline Coaxial & 2 & $50 \mathrm{Ohm} \mathrm{RG}-174$ & $\begin{array}{l}\text { Coaxial Pin } \\
\text { Connector }\end{array}$ \\
\hline Water/Air & 3 & $\begin{array}{l}1 / 4 \text { inch } 1 . D \text {. } \\
\text { Hose (150 psi) }\end{array}$ & $\begin{array}{l}1 \text { for air } \\
\text { purge*, } \\
1 \text { air, } \\
1 \text { air/water }\end{array}$ \\
\hline Conduit & 1 & $\begin{array}{l}1 / 2 \text { inch I.D. } \\
\text { flexible }\end{array}$ & $\begin{array}{l}\text { (for adding } \\
\text { future services) }\end{array}$ \\
\hline
\end{tabular}

* To meet the requirements for qualification under the National Electric Code for Class I, Division I, Group B components (see Appendix B). 


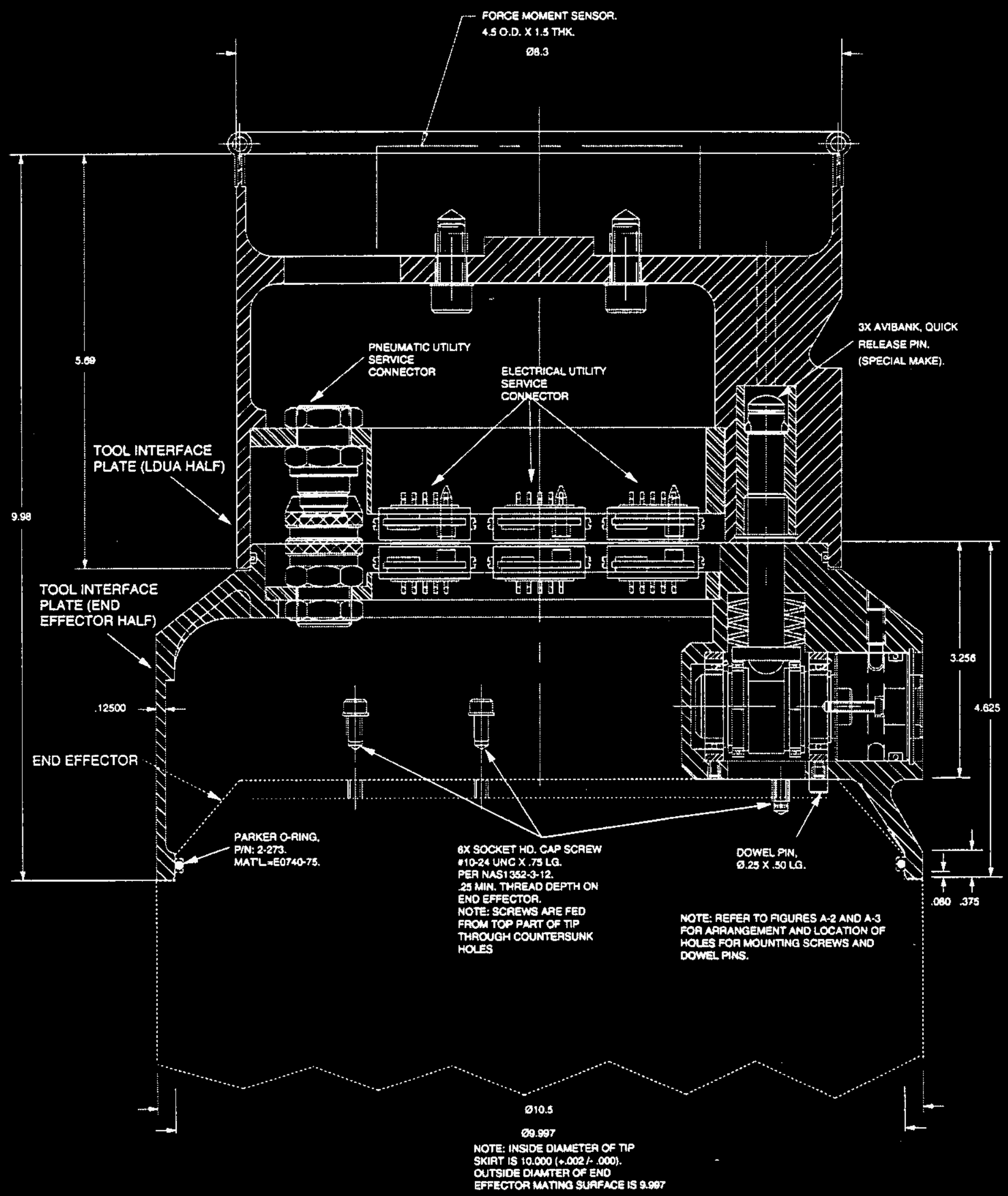

Figure A-1 TIP Assembly Showing Fnd Effector Mounting 


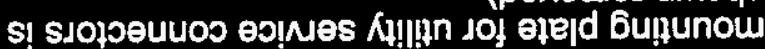

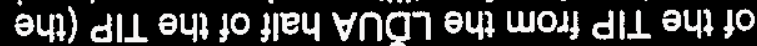

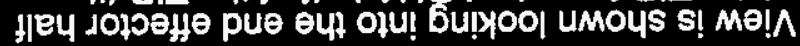

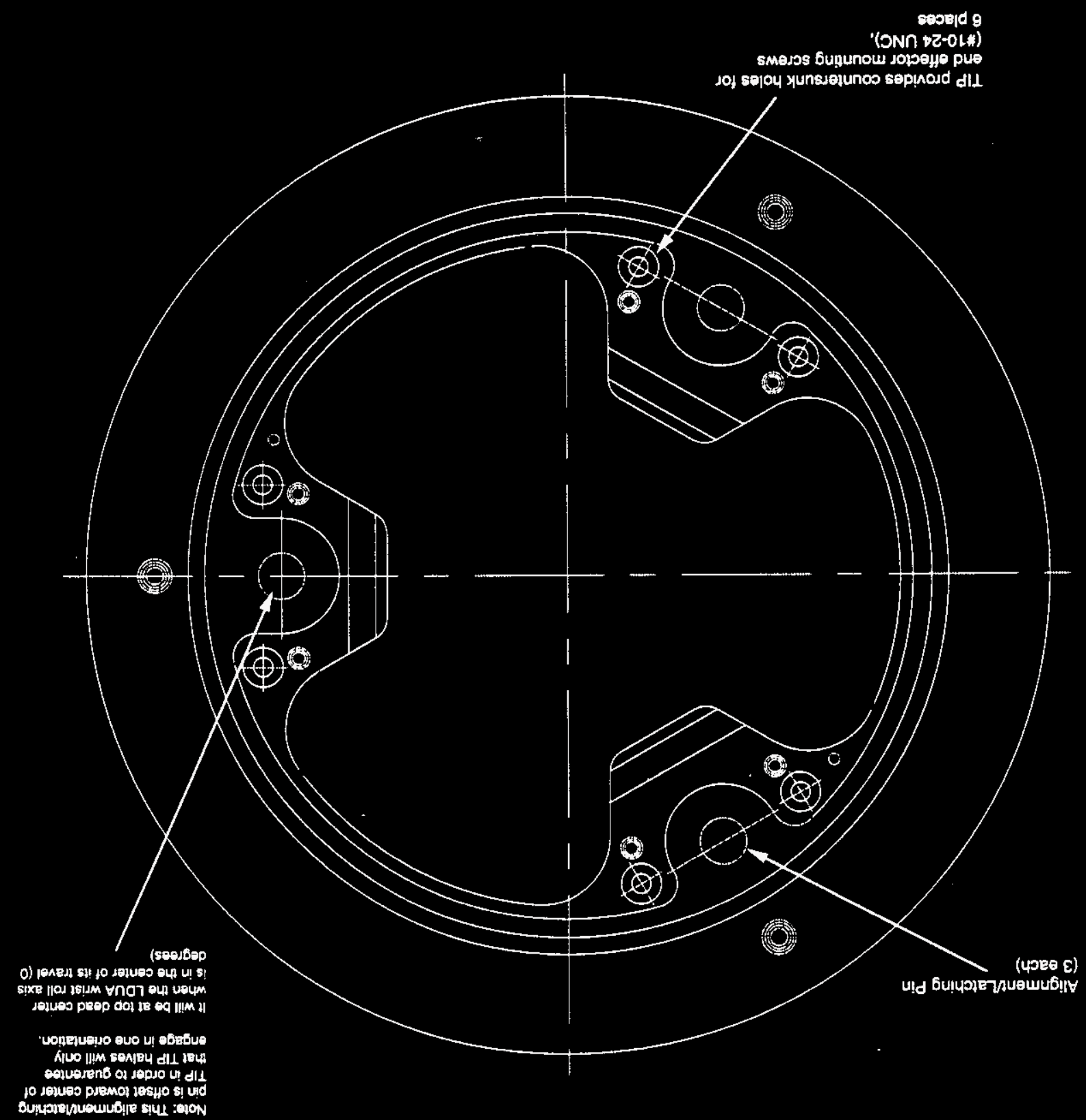




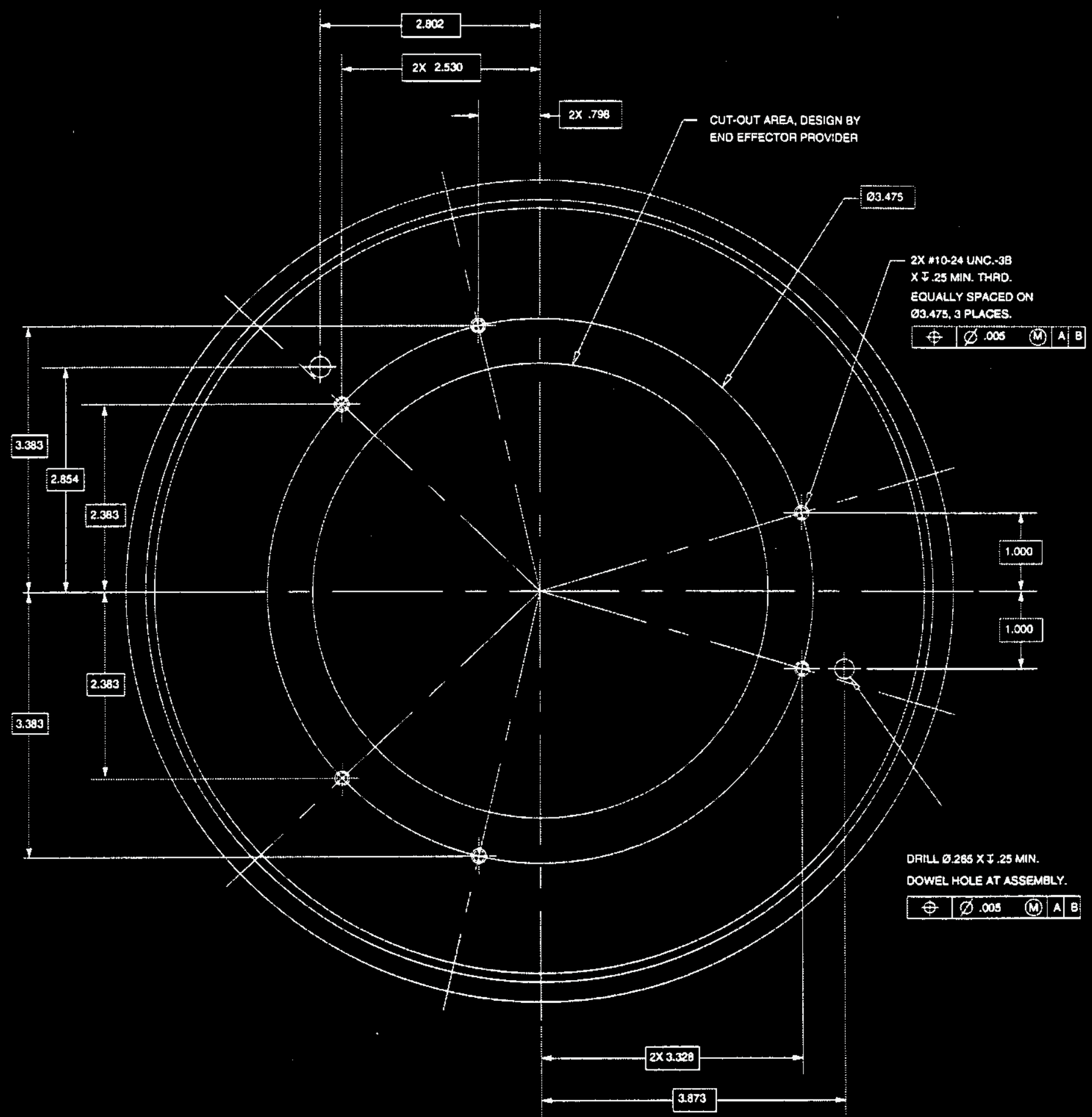

View is shown looking at mating surface of end effector from TIP

Figure A-3 Hole Locations For Find Effector Mounting 


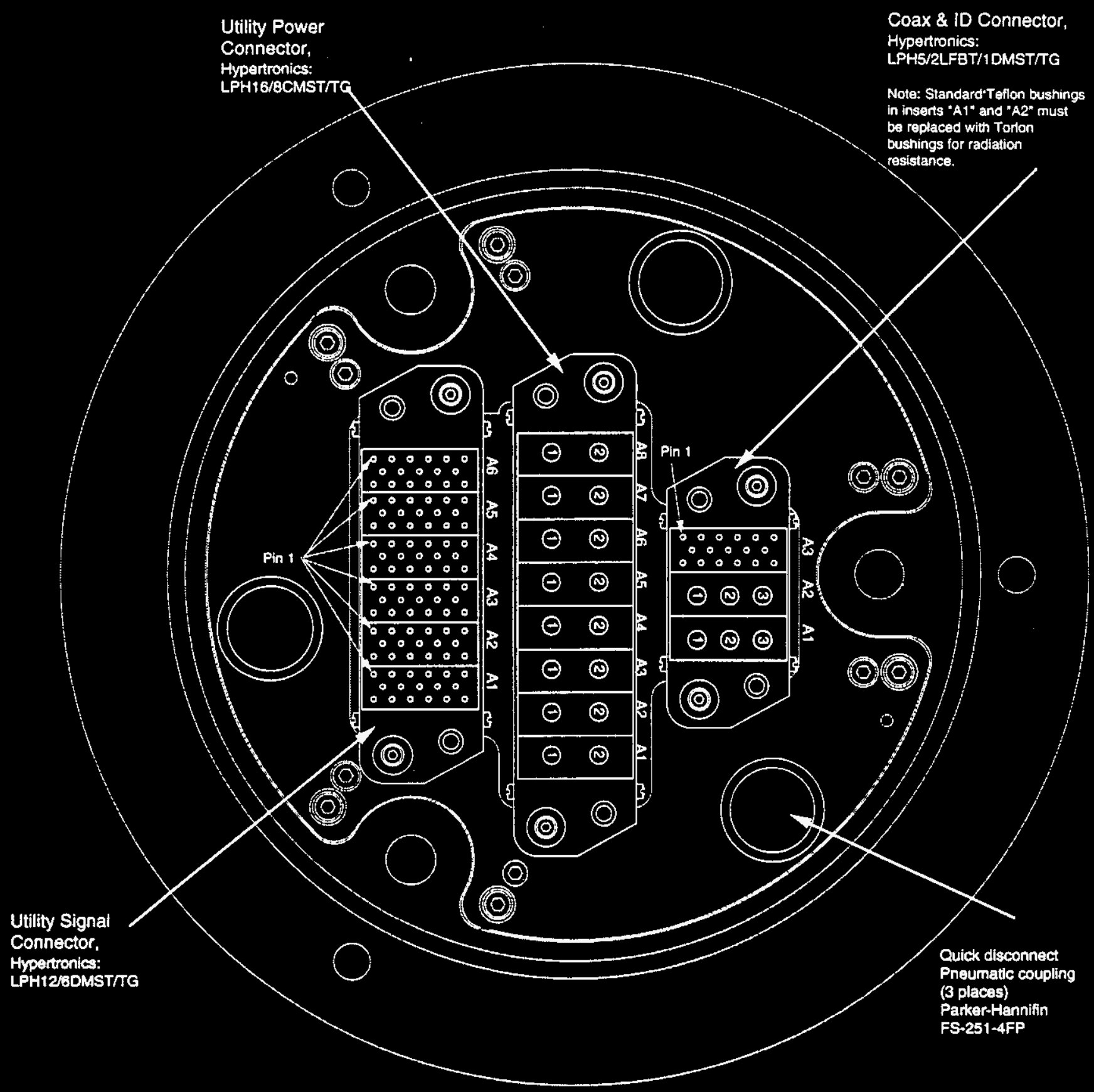

View is shown looking into the end effector half of the TIP from the LDUA half of the TIP 


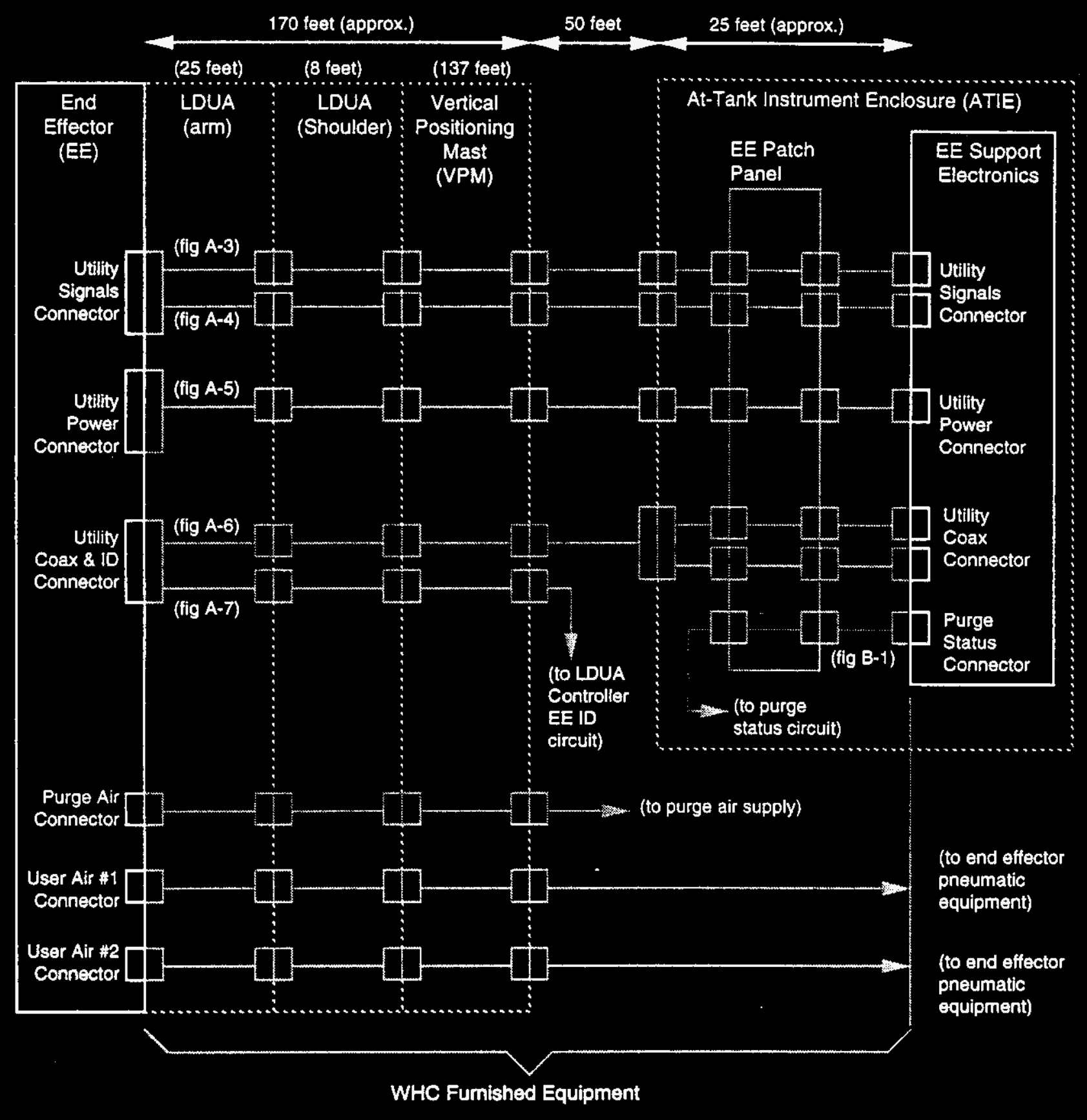

Figure A-5 TIP Utilfty Services 


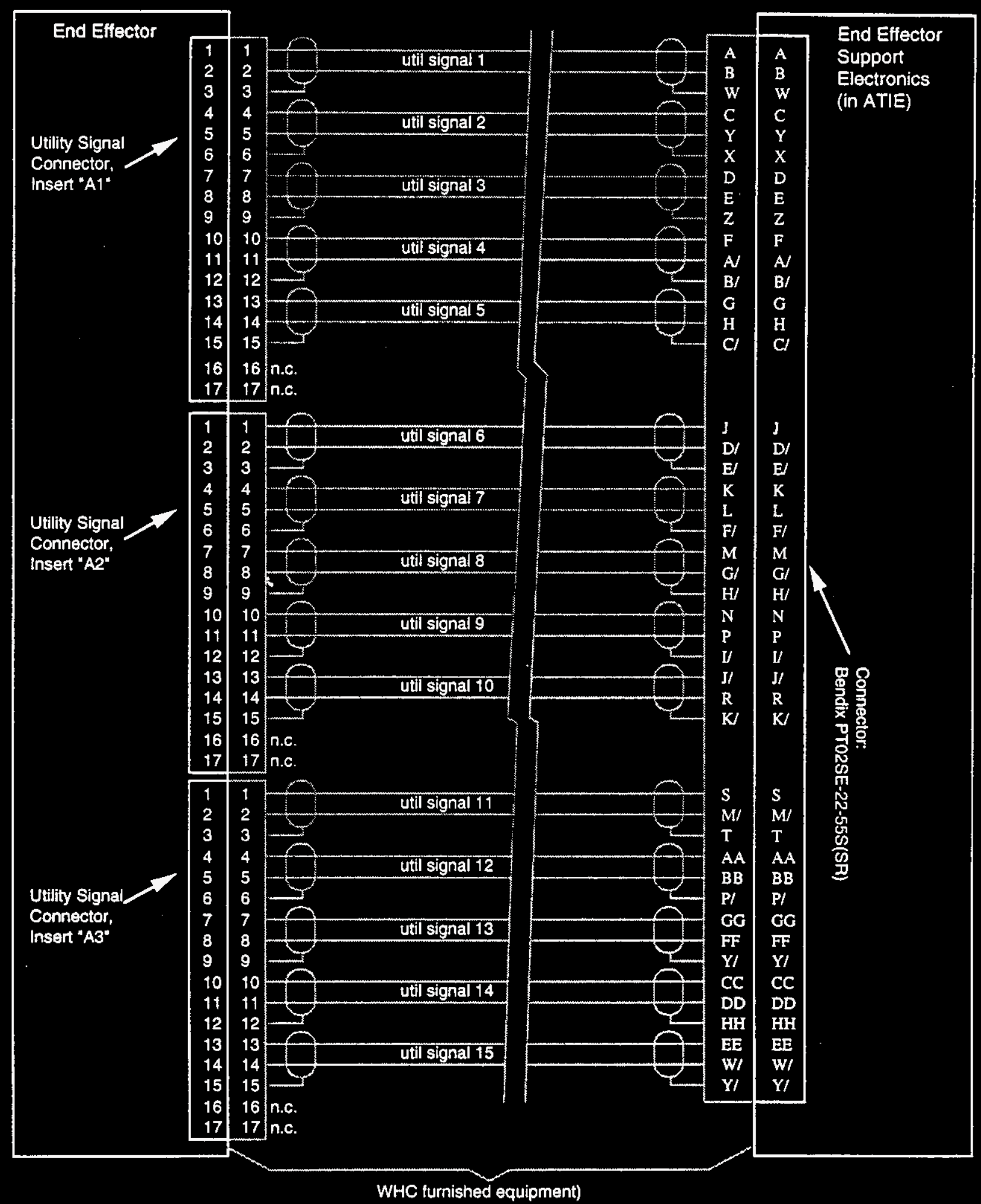

Figure A-6 Interface Wiring For BE Utility Signals 1-15 


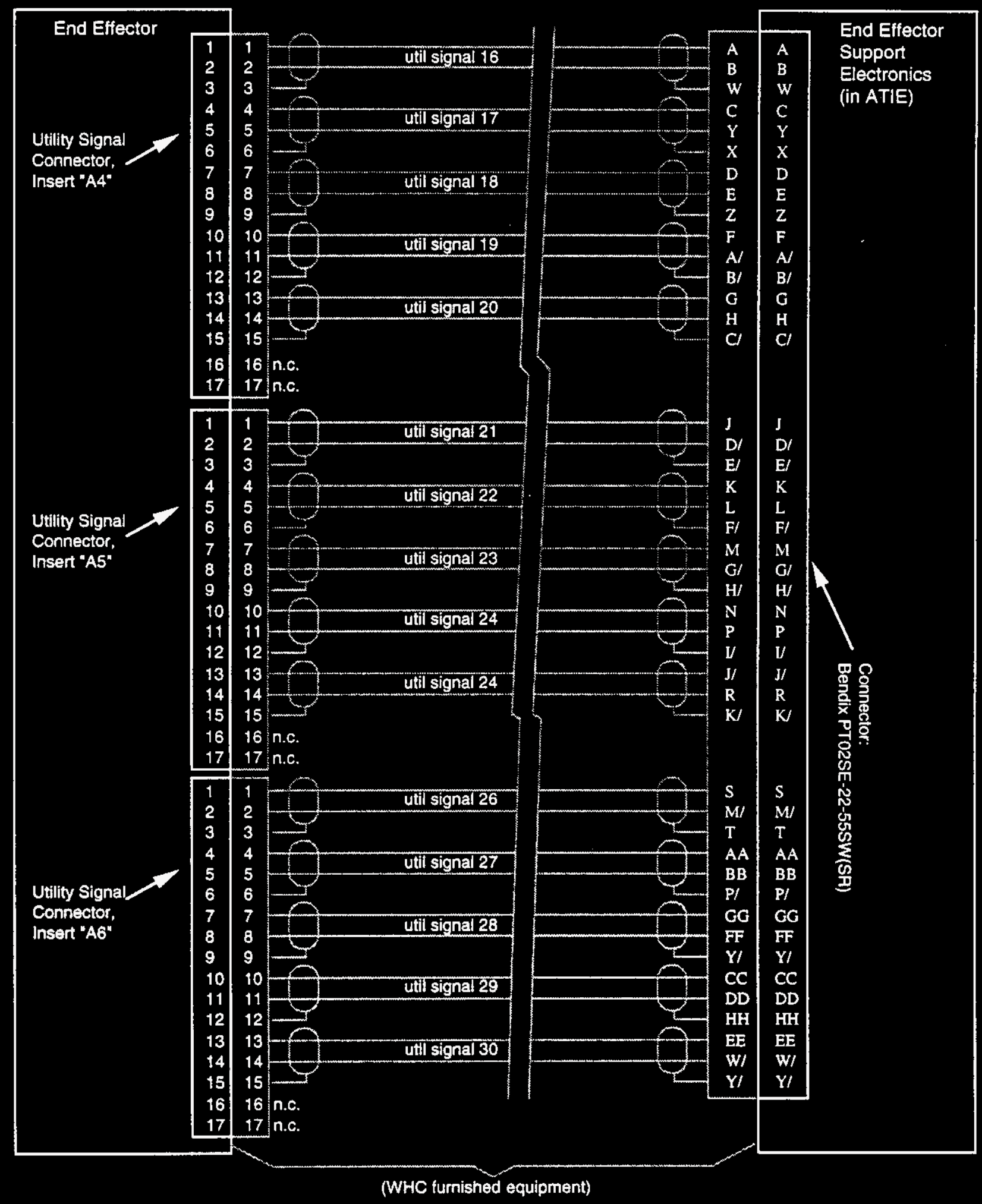

Figure A-7 Interface wiring For EE Utility Signals 16-30 


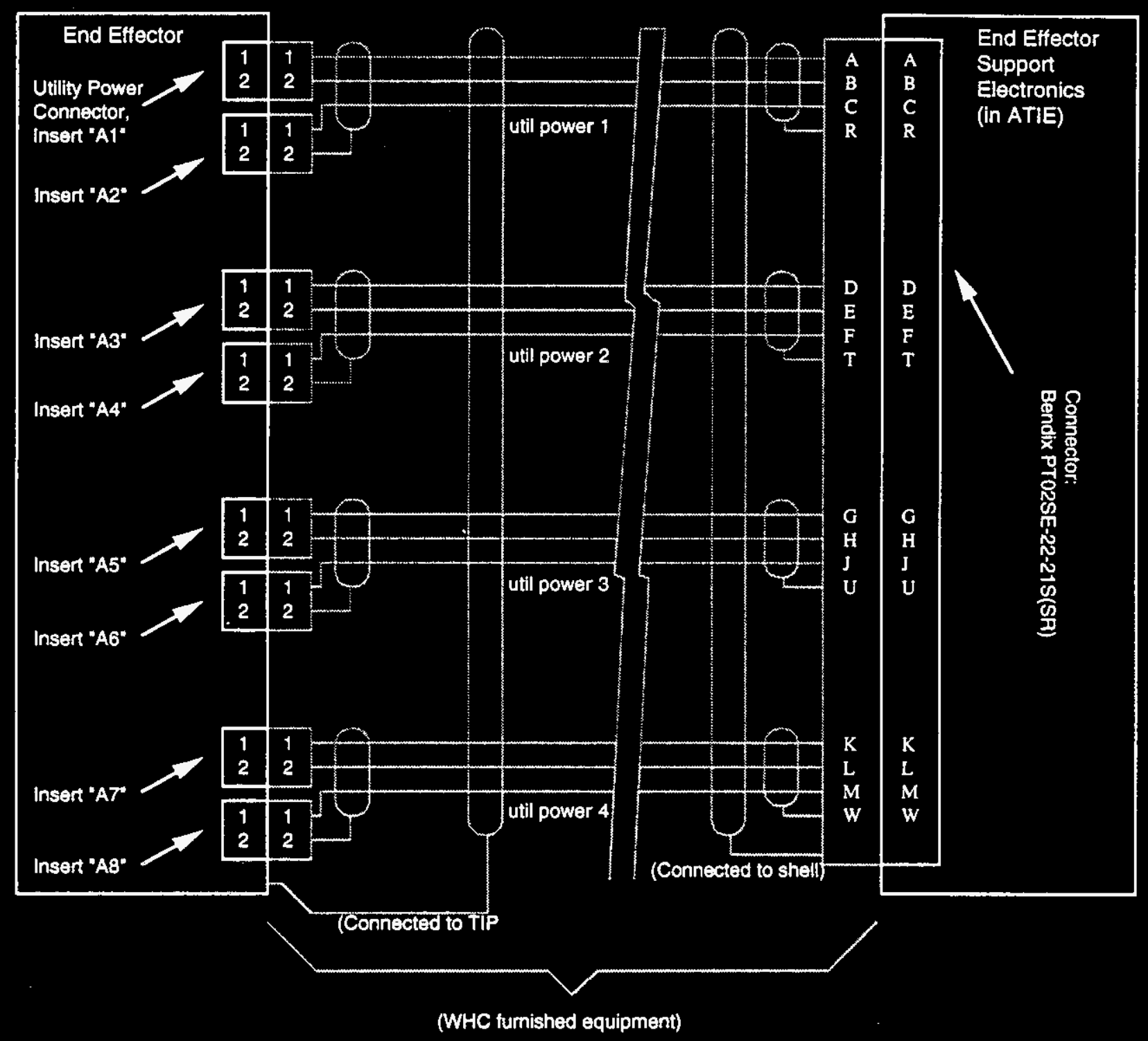

Figure A-8 Interface Wiring For EB Utility Power 


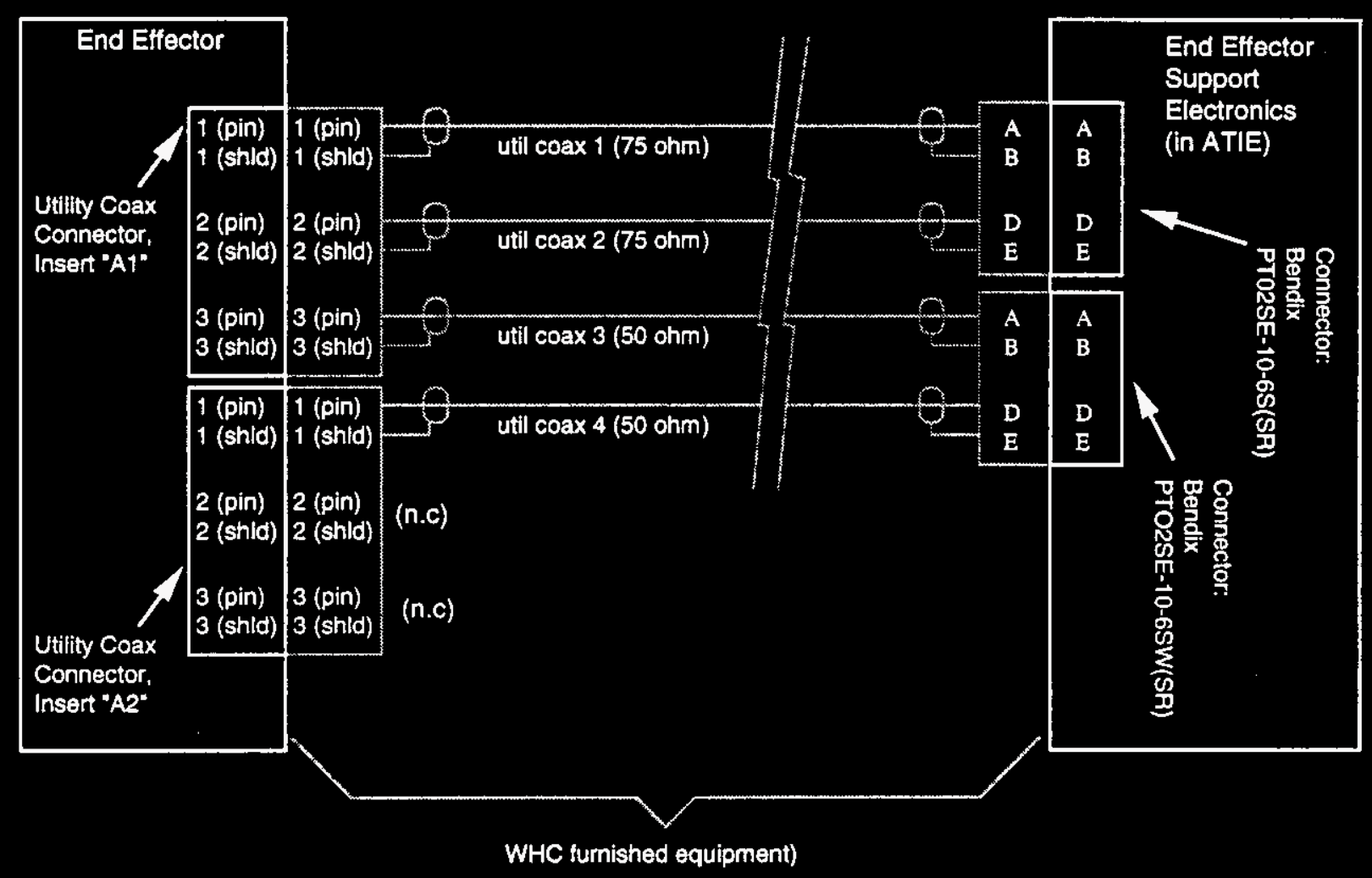

Figure A-9 Interface Wiring For EE Coaxial Cables 


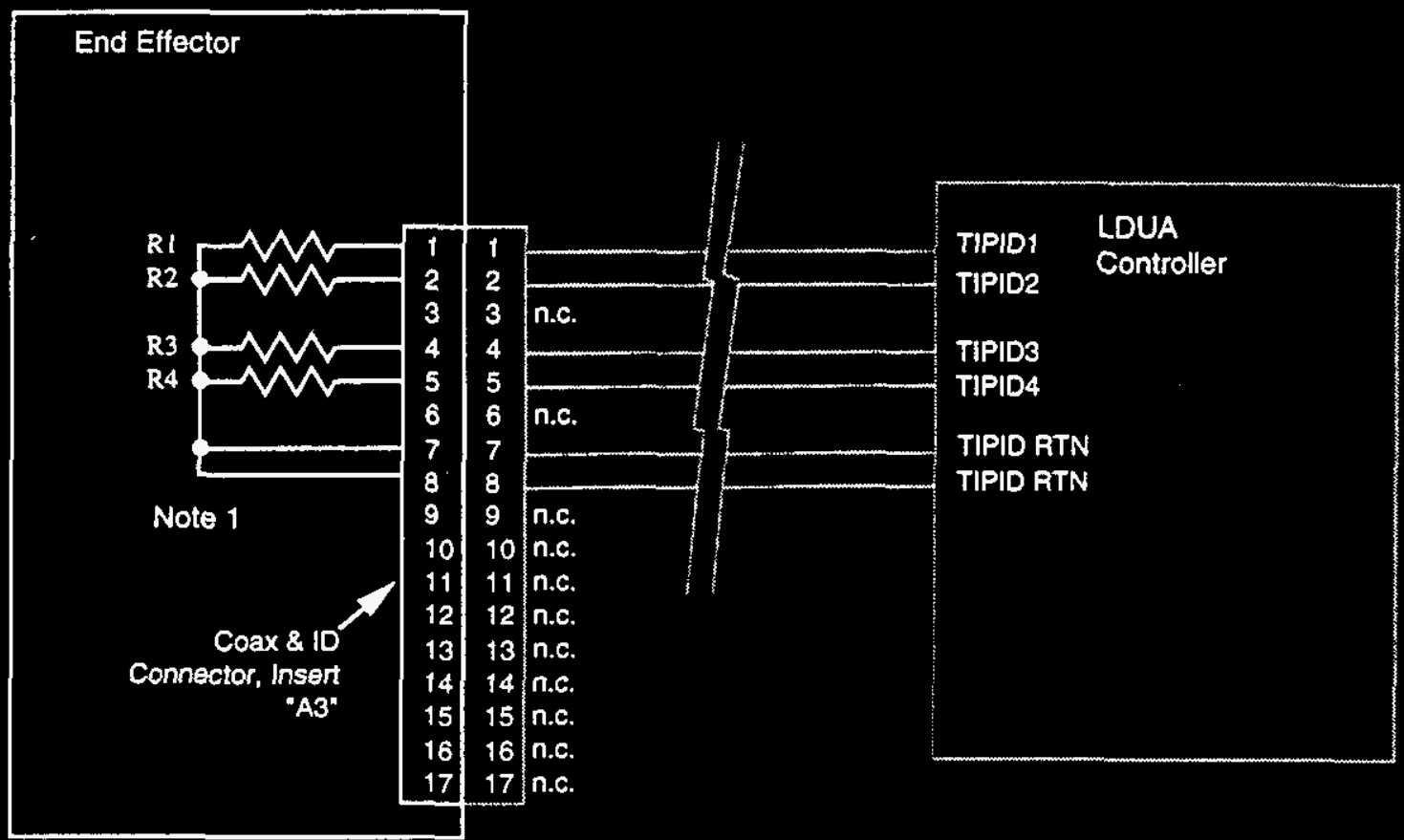

Note 1: An electronically readable identification number is established in the end effector by a suitable combination of resistor values. The customer is responsible for assigning EE identification numbers, and the EE provider is responsible for implementing the identification circuit. (Resistors are standard 0.25 watt, 5 per cent units).

\begin{tabular}{|c|c|c|c|c|}
\hline $\begin{array}{l}\text { EE } \\
\text { Identification } \\
\text { Number }\end{array}$ & $\mathbf{R} 4$ & $\mathbf{R 3}$ & $\mathbf{R} 2$ & $\mathbf{R} 1$ \\
\hline 0 & 820 & 820 & 820 & 820 \\
\hline 1 & 820 & 820 & 820 & $6.2 \mathrm{~K}$ \\
\hline 2 & 820 & 820 & $6.2 \mathrm{~K}$ & 820 \\
\hline 3 & 820 & 820 & $6.2 \mathrm{~K}$ & $6.2 \mathrm{~K}$ \\
\hline 4 & 820 & $6.2 \mathrm{~K}$ & 820 & 820 \\
\hline 5 & 820 & $6.2 \mathrm{~K}$ & 820 & $6.2 \mathrm{~K}$ \\
\hline 6 & 820 & $6.2 \mathrm{~K}$ & $6.2 \mathrm{~K}$ & 820 \\
\hline 7 & 820 & $6.2 \mathrm{~K}$ & $6.2 \mathrm{~K}$ & $6.2 \mathrm{~K}$ \\
\hline 8 & $6.2 \mathrm{~K}$ & 820 & 820 & 820 \\
\hline 9 & $6.2 \mathrm{~K}$ & 8220 & 820 & $6.2 \mathrm{~K}$ \\
\hline 10 & $6.2 \mathrm{~K}$ & 820 & $6.2 \mathrm{~K}$ & 820 \\
\hline 11 & $6.2 \mathrm{~K}$ & 820 & $6.2 \mathrm{~K}$ & $6.2 \mathrm{~K}$ \\
\hline 12 & $6.2 \mathrm{~K}$ & $6.2 \mathrm{~K}$ & 820 & 820 \\
\hline 13 & $6.2 \mathrm{~K}$ & $6.2 \mathrm{~K}$ & 820 & $6.2 \mathrm{~K}$ \\
\hline 14 & $6.2 \mathrm{~K}$ & $6.2 \mathrm{~K}$ & $6.2 \mathrm{~K}$ & 820 \\
\hline 15 & $6.2 \mathrm{~K}$ & $6.2 \mathrm{~K}$ & $6.2 \mathrm{~K}$ & $6.2 \mathrm{~K}$ \\
\hline
\end{tabular}

Figure A-10 Interface Wiring For ED Identification Circuit 
The LDUA System is purged by a constant low flow of instrument grade (clean, low moisture) air. This purge flow enables it to meet National Electric Code requirements for operation in Class 1 , Division 1 , Group $B$ flammable atmospheres by maintaining the internal pressure of the end effector, LDUA, and VPM above the pressure of the external atmosphere (in accordance with National Fire Protection Association [NFPA] 496\%). Th is pressure differential also keeps the interior surfaces of these components from becoming contaminated in the event of seal leakage. Purge air is carried into the end effector by one of the pneumatic utility service lines. The purge air is released into the end effector and flows through it into the LDUA via vent openings provided in the TIP. The purge flow continues through the whole length of the LDUA and into the inner and then outer VPM tubes. From the outer VPM tube, it passes into the VPM housing fron where it is exhausted into the TRIC. Differential pressure sensors monitor the purge pressure in the inner VPM tube and the VPM housing. These sensors are referenced to the tank pressure, which is obtained by a pressure tap below the Riser Isolation Valve. An alarm is generated if the pressure falls below the required level. In addition, the LDUA control system can be selectively enabled to remove all electrical power from the purged volume (this mode is enabled when operating in tanks with flammable atmospheres and disabled when operating in nonflammable tanks).

In order to properly operate with the LDUA purge system, the end effector and its support equipment shall:

1. Maintain purge air flow path: The end effector shall arrange for purge air to flow from the designated pneumatic utility service connector in the TIP into the end effector, sweep the internal volume of the end effector, and pass from the end effector into the LDUA via the air flow passages in the TIP.

2. Interrupt electrical power on loss of purge pressure: The support electronics for the end effector shall remove electrical power from the end effector upon loss of purge pressure in accordance with NFPA 496. The recommended method to do this is by using a purge pressure status signal that is available in the At-Tank Instrument Enclosure (ATIE) (refer to Figure B-1). This signal originates with the LDUA purge pressure sensors and is in the form of a set of relay contacts that open when LDUA purge pressure falls below the acceptable limit.

Alternatively, the end effector may arrange to provide its own sensors to monitor the differential pressure between its internal volume and the tank atmosphere. In that case, the end effector provider is responsible for all other aspects of NFPA 496, including the provision for there being a time delay in restoring power following loss of pressure.

3. Withstand single point failures: There shall not be any single point failures that could prevent the removal of electrical power from the end effector when purge pressure is insufficient.

7 National Fire Protection Association, "Purged and Pressurized Enclosures for Electrical Equipment" 


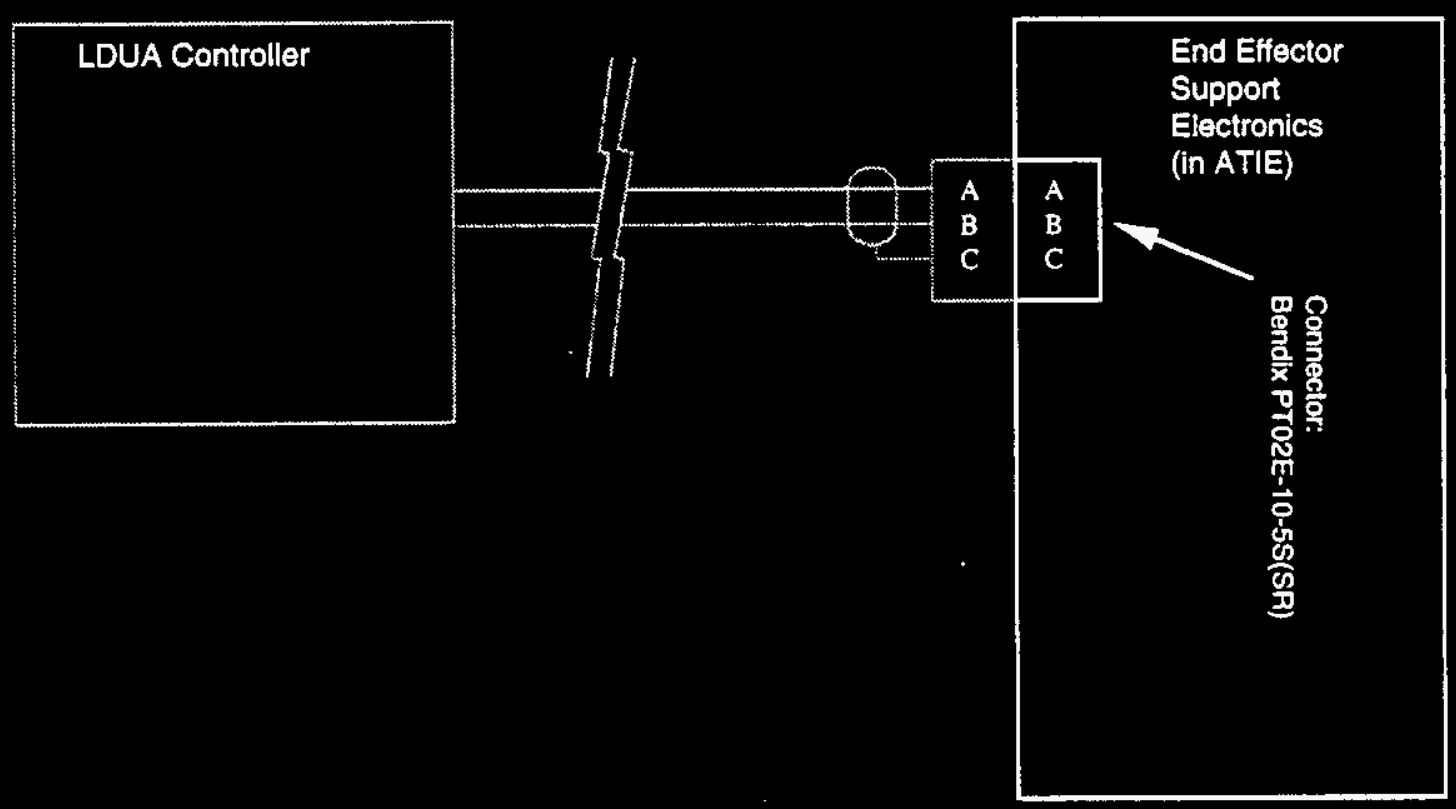

Figure B-1 Interface Wiring For Purge status Circuit 
DISTRIBUTION SHEET

\begin{tabular}{|c|c|c|c|c|c|}
\hline \multirow{2}{*}{$\begin{array}{l}\text { To } \\
\text { Distribution }\end{array}$} & \multirow{2}{*}{\multicolumn{3}{|c|}{$\begin{array}{l}\text { From } \\
\text { G. R. Kiebel/Remote System and } \\
\text { Sensor Applications }\end{array}$}} & \multicolumn{2}{|l|}{ Page 1 of 1} \\
\hline & & & & \multicolumn{2}{|c|}{ Date $12 / 11 / 95$} \\
\hline \multirow{2}{*}{\multicolumn{4}{|c|}{$\begin{array}{l}\text { Project Title/Work Order } \\
\text { Light Duty Utility Arm }\end{array}$}} & \multirow{2}{*}{\multicolumn{2}{|c|}{$\begin{array}{l}\text { EDT No. } \\
\text { ECN No. } 165799\end{array}$}} \\
\hline & & & & & \\
\hline Name & MSIN & $\begin{array}{l}\text { Text } \\
\text { With All } \\
\text { Attach. }\end{array}$ & Text Only & $\begin{array}{l}\text { Attach./ } \\
\text { Appendix } \\
\text { Only }\end{array}$ & $\begin{array}{l}\text { EDT/ECN } \\
\text { Only }\end{array}$ \\
\hline $\begin{array}{l}\text { B. A. Carteret } \\
\text { D. S. Dutt } \\
\text { G. R. Kiebe1 } \\
\text { A. F. Pardini } \\
\text { T. J. Samuel } \\
\text { LDUA Project File 2.1.5.1 (10) }\end{array}$ & $\begin{array}{l}N 1-21 \\
N 1-21 \\
N 1-21 \\
N 1-21 \\
N 1-21 \\
N 1-21\end{array}$ & $\begin{array}{l}X \\
X \\
X \\
X \\
X \\
X\end{array}$ & & & \\
\hline $\begin{array}{l}\text { Cantral Files oriq }+1 \\
\text { Ost }\end{array}$ & $\begin{array}{l}A 3-85 \\
E \leqslant\end{array}$ & $x$ & & & \\
\hline
\end{tabular}

